\title{
The Effect of Indonesia's Economic Crisis on Small Farmers and Natural Forest Cover in the Outer Islands
}

William D. Sunderlin,

Ida Aju Pradnja Resosudarmo,

Edy Rianto, and

Arild Angelsen

CENTER FOR INTERNATIONAL FORESTRY RESEARCH

Office address: Jalan CIFOR, Situ Gede, Sindang Barang, Bogor 16680, Indonesia

Mailing address: P.O. Box 6596 JKPWB, Jakarta 10065, Indonesia

Tel.: +62 (251) 622622; Fax: +62 (251) 622100

E-mail: cifor@cgiar.org

Website: http://www.cgiar.org/cifor 


\section{The CGIAR System}

The Consultative Group on International Agricultural Research (CGIAR) is an informal association of 41 public and private sector donors that supports a network of sixteen international agricultural research institutes, CIFOR being the newest of these. The Group was established in 1971. The CGIAR Centers are part of a global agricultural research system which endeavours to apply international scientific capacity to solving of the problems of the world's disadvantaged people.

\section{CIFOR}

CIFOR was established under the CGIAR system in response to global concerns about the social, environmental and economic consequences of loss and degradation of forests. It operates through a series of highly decentralised partnerships with key institutions and/or individuals throughout the developing and industrialised worlds. The nature and duration of these partnerships are determined by the specific research problems being addressed. This research agenda is under constant review and is subject to change as the partners recognise new opportunities and problems. 


\section{The Effect of Indonesia's Economic Crisis on Small Farmers and Natural Forest Cover in the Outer Islands}

William D. Sunderlin,

Ida Aju Pradnja Resosudarmo,

Edy Rianto, and

Arild Angelsen
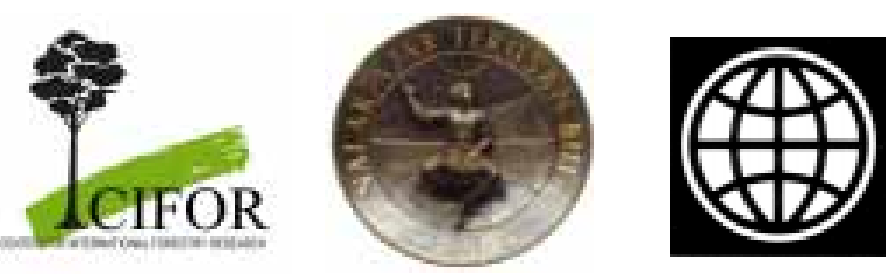

$\frac{\text { THE JOHN D. A D KATHEMINE T }}{\text { MACARTHUR FOUNDATION }}$ 


\section{Contents}

Abstract

1. Introduction 1

2. Theory, questions and hypotheses 3

3. Methodology 5

3.1 Sample frame and field research locations 6

$\begin{array}{ll}3.2 & \text { The preliminary census }\end{array}$

3.3 Survey respondents, questions posed and approach 6

$\begin{array}{lll}3.4 & \text { Qualitative survey } & 8\end{array}$

$\begin{array}{ll}3.5 \text { Survey on migration } & 8\end{array}$

4. Findings 8

$\begin{array}{lll}4.1 & \text { Study household characteristics } & 8\end{array}$

4.2 Effects on wellbeing of small farmers 9

$\begin{array}{lll}4.3 & \text { Effects on natural forest cover } & 19\end{array}$

4.4 Summary of major findings $\quad 26$

$\begin{array}{lll}4.5 & \text { Unresolved questions } & 27\end{array}$

5. Conclusions and recommendations 28

$\begin{array}{lr}\text { Acknowledgements } & 29\end{array}$

$\begin{array}{lr}\text { Endnotes } & 29\end{array}$

References 31

Appendices: 33

Appendix 1. Derivation of estimates of the number of swidden cultivators and forest villagers in the main outer islands of Indonesia 33

Appendix 2. Criteria for the selection of the study villages 34

Appendix 3. Strengths and weaknesses of the sample frame 35

Appendix 4. Stratification of the census data for selection of the household survey respondents 


\section{List of Figures}

Figure 1. Commodity price index in terms of food consumer price index, January 1997 - September 1999.

Figure 2. Map of Indonesia showing the research provinces and villages. 7

Figure 3. Reference years in the recall approach. 8

Figure 4. Study households by primary crops produced in 1998-99, all provinces.

Figure 5. Study households by primary crop produced in 1998-99 and by study provinces.

Figure 6. Degree of dependence of households on export commodity income in 1998-99.

Figure 7. View of respondents on their status in period 3 (1998-1999) as compared to period 1 (1996-1997).

Figure 8. Classification of study households by crisis experience and study provinces.

Figure 9. Classification of study households according to perceived crisis experience and main income-producing crop in 1998-99.

Figure 10. How did households perceiving themselves as worse off cope? 14

Figure 11. How did households perceiving themselves as better off use their extra income?

Figure 12. Number of study households receiving cash income from forest resources, comparison of periods 1, 2 and 3 .

Figure 13. Number of households receiving cash income from forest resources, by study province and by study period.

Figure 14. Number of households receiving cash income from forest resources, by resource type and by study period.

Figure 15. Comparison of gross average household income and average household expenditure for agricultural inputs, pre-crisis and crisis periods.

Figure 16. Average household expenditure for agricultural inputs in 1996-97, 1997-98 and 1998-99.

Figure 17. Average household expenditure for agricultural inputs by main income-producing crop, 1996-97, 1997-98 and 1998-99.

Figure 18. Clearings of land for agriculture in 1996-1999 according to intended purpose.

Figure 19. Total area of land cleared by study households during the crisis (mid-1997 to mid-1999), by province and by land cover type.

Figure 20. Change in the area of export crops and of food crops, second year of crisis (1998-99) as compared to year before crisis (1996-97).

Figure 21. Proportion of respondents clearing and not clearing land, by type of experience during the crisis.

Figure 22. Average area of land cleared per household, by type of experience during the crisis. 


\section{List of Tables}

Table 1. Sample frame for the study provinces, villages, and households. 6

Table 2. Independent means test of estimated total household income, differentiated by high- and no/low-ECl, pre-crisis and crisis.

Table 3. Perception of household wellbeing during 1998-99 as compared to 1996-97, by level of export commodity income in 1998-99.

Table 4. Respondent perception of whether the 1997-98 drought and fires influences them, by study provinces.

Table 5. Respondent perception of whether the economic crisis or the 1997-98 drought and fires had a worse effect, by study provinces.

Table 6. Relationship between crisis experience and ability to save.

Table 7. Relationship between perceived crisis experience and receiving government aid during the crisis.

Table 8. Independent means test comparison of level of government aid received by those who perceive themselves as better and worse off during the crisis, and by those with high and no/low ECl.

Table 9. Proportion of study households clearing land during the crisis (periods 2 and 3) by province.

Table 10. Chi-square analysis of who clears land during the crisis (periods 2 and 3 ) by level of export commodity income (high or low).

Table 11. Independent means test of average area of land cleared, differentiated by high and no/low $\mathrm{ECl}$, pre-crisis and crisis.

Table 12. Number of land clearings by primary crop type (in terms of value) over the lifetime of the parcel, in periods 1, 2 and 3 .

Table 13. Average area of land cultivated per household by study periods and by perceived crisis experience.

Table 14. Average area of land cultivated per household by study periods and by grouping of main crop type according to degree of success in facing the crisis (high, intermediate, low). 


\title{
The Effect of Indonesia's Economic Crisis on Small Farmers and Natural Forest Cover in the Outer Islands
}

\author{
William D. Sunderlin, ${ }^{*}$ Ida Aju Pradnja Resosudarmo, ${ }^{*}$ \\ Edy Rianto, ${ }^{*}$ and Arild Angelsen**
}

\begin{abstract}
Twenty million people live in or near Indonesia's natural forests. The country's humid tropical forests, among the most extensive remaining in the world, are primarily in Sumatra, Kalimantan, Sulawesi, and Irian Jaya. A devastating regional economic crisis that began in mid-1997 affected Indonesia more strongly than any other country in Asia.

A random sample survey of 1,050 households was conducted in six outer island provinces to understand the effects of the crisis on the wellbeing of forest villagers and on their agricultural and forest clearing practices. In particular, the study sought to understand diverging opportunities introduced by the drastic depreciation of the Indonesian rupiah against the U.S. dollar: on one hand producers of agro-export commodities could get an income windfall from higher market prices; on the other hand increased costs of living could neutralise potential income gains.

Among the key findings of the research are: (1) two-thirds of the study households reported they were worse off and only one-fifth reported they were better off during the crisis than in the year before the crisis;

(2) this happened in spite of the fact that three-quarters of study households had export commodity income;

(3) clearing of forest land increased slightly in the first year of the crisis and greatly in the second year of the crisis; (4) land was cleared increasingly for export tree crops in sedentary systems and less for food crops in swidden cultivation systems; and (5) those who perceived themselves as worse off or better off were more likely to have cleared land during the crisis, and to have cleared a larger area of land, than those who felt their wellbeing did not change significantly.

Contrary to the common assumption that rural Indonesians were generally unaffected by the crisis, forest villagers perceived themselves as worse off during the crisis than before. Moreover, additional pressure has been put on forests, in spite of any conclusions that might be drawn from the turn toward increased sedentary farming during the crisis. Key policy lessons are that: (1) farmers need assistance in diversifying their income sources to help protect them against possible future economic shocks; and (2) there should be greater awareness of how macroeconomic instability can lead to undesirable environmental consequences.
\end{abstract}

\section{Introduction}

This paper reports research findings on the effect of Indonesia's economic crisis on the wellbeing of people living in or near the country's natural forests, on their agricultural systems, and on the forests that they manage. An appropriate point of departure is to review basic facts concerning the crisis and the role of agriculture in the midst of the crisis.

Beginning in mid-1997 Asian countries succumbed to a regional economic crisis caused by the depreciation of their currencies against the U.S. dollar. Among all Asian countries, Indonesia suffered the most. According to one analyst, "Indonesia's economic collapse is the most profound to affect any significant market-oriented economy in decades" (Evans 1998:5). Whereas the Indonesian economy grew at an annual average rate of $6.5 \%$ in the period 1967-1997, the economy contracted 13.6\% in 1998 (Hill 1999:23). It is projected that growth will be 0.8\% in 1999 (EIU 1999:11). The rupiah (Rp.) has declined in value from Rp. 2,400 in July 1997 to an average of Rp. 8,300 in the period September 1997 through September 1999. (The rupiah briefly reached a

\footnotetext{
* Center for International Forestry Research (CIFOR), Bogor, Indonesia.

** Department of Economics and Social Science, Agricultural University of Norway, Ås, Norway.
} 
record low at around Rp. 16,000 - 17,000 to the dollar in January and again in July 1998, and has been in the range of Rp. 8,000 for most of the time since then.) Among the manifestations of the economic crisis have been an increase in the aggregate rate of poverty from $11 \%$ in 1996 to $14-20 \%$ in 1998 (Poppele et al. 1999:14), increasing unemployment, rampant inflation and loss of consumer purchasing power, grave social instability, and the collapse of the 32-year tenure of Suharto as president of the country in May 1998.

The dramatic decrease of the value of the rupiah has been two-edged. On one hand it led to the paralysis of the mainly urban economic sectors that are highly U.S. dollardependent. The construction, industrial and banking sectors have been devastated by their inability to finance imports of necessary inputs and/or by their inability to service dollar-denominated debts. On the other hand the rural sectors such as agriculture, that are relatively dollarindependent, have been comparatively sheltered from the worst effects of the crisis.

Since the early days of the crisis, experts and policy-makers have urged special attention to agriculture (and notably export agriculture) as a means of leading the way out of the crisis. Among the arguments for the special status of agriculture are the following. First, there are high export income-growth possibilities enabled by the depreciation of the rupiah against the U.S. dollar ${ }^{1}$ and by the relatively low U.S. dollar cost in agricultural production. Second, agriculture is labour-intensive ${ }^{2}$ and serves as an important means to relieve unemployment at a time when maintaining the conditions of stable rule is a key strategic priority of the government. Third, and equally important in terms of government efforts to maintain stability, agriculture supplies basic needs commodities. Fourth, domestic production of crops that are otherwise imported not only relieves unemployment and supplies basic needs, but also frees up scarce foreign exchange reserves for other purposes. For the reasons mentioned here, agricultural sectors have performed better than economies as a whole in most other developing countries experiencing economic crisis in recent years. In most countries the relative contribution of agriculture tends to decline as economies boom, and grow as they falter.

Faith placed in the agricultural sector has, in general, been justified. From the onset of the crisis through the third quarter of 1998, the agricultural sector (including agriculture, forestry and fisheries) showed between zero and $1 \%$ growth, outperforming all other sectors (NRMP 1999:7). Moreover, from 1997 to 1998, agriculture's share of the total workforce expanded from $40.7 \%$ to $45.0 \%$ and it was the only sector in which this occurred (Hill 1999:39).
The research project on which this paper is based poses two broad questions:

(1) What are the effects of Indonesia's economic crisis on the wellbeing of small farmers in or nearby natural forest areas?; and

(2) What are the effects of the crisis on these small farmers' agricultural practices and how does this in turn affect natural forest cover?

The first research question is important because there are approximately 20 million people who live in or near natural forests in Indonesia's five main outer islands. This population includes approximately six million people in swidden cultivator households. (For the derivation of these population figures, see Appendix 1.) Small farmers in forest villages may be among the most disadvantaged and vulnerable people in Indonesia. This segment of the rural population faces opportunities and constraints that are different from those of the population at large. An effort to understand the impact of the crisis on their lives must be carried out with due attention to these differences.

No major research has yet been carried out on the impact of the crisis as it affects the wellbeing of this particular sub-group of farmers. There have, however, been various reports claiming that rural Indonesians in general, especially those outside of Java, have suffered relatively little from the crisis, and that some have in fact prospered. For example, Evans (1998:34) says people outside Java "have been doing somewhat better (than people in Java), with their tradable commodities securing higher prices (at least in rupiah terms)". From May 1997 to May 1998, farmers' terms of trade were lower in Java, but higher in Bali, Sulawesi and Sumatra (Evans 1998:28). Hill (1999:27-28, 45) agrees with other researchers in assuming that, generally speaking, people in rural areas have either not been badly affected by the crisis or have actually benefited from the depreciation of the rupiah. ${ }^{3}$ Jellinek and Rustanto (1999) conclude that the Javanese poor have not suffered greatly because of resilience in the agricultural and informal sectors. Booth (1999:137) believes the devaluation [sic] will increase the rupiah price of agricultural products and boost producer incomes. One exception to this general consensus is Warr (1999:27) who says " ... a high proportion of poor people, including many agricultural producers, seem to have been harmed, especially those who are net producers of food".

The second research question on the effects on natural forests is justified by the fact that it is commonly assumed that small farmers, notably those involved in swidden cultivation (or "shifting cultivation" as it is often called), are an important cause of deforestation in Indonesia. ${ }^{4}$ According to Fraser (1998:143-145), most of the estimated 1 million ha annual loss of forest cover in 
Indonesia is explained by growth in the population of small farmers living in forested areas. It stands to reason that if the crisis were to have a significant impact on the livelihoods of these farmers, then it might also have a discernible effect on their agricultural fallows and forest clearing practices. ${ }^{5}$ It is important to note that over time in Indonesia, there has been a gradual trend away from swidden cultivation and toward production of tree crops in sedentary agricultural systems of the former in comparison to the latter, because of declining profitability (van Noordwijk et al. 1995:11-12; Tomich et al. 1998:6569). ${ }^{6}$ It is important to know how the economic crisis has affected the comparative profitability of these two agricultural systems.

No major research findings have yet been published on the second question. There have, however, been numerous media reports on forest clearing related to the increased price of particular export commodities. Notable among these are articles on the clearing of coastal mangrove forests for the establishment of shrimp aquaculture, as well as articles on increased interest in the cultivation of cocoa, coffee and pepper. ${ }^{7}$

This paper is comprised of four subsequent sections. Section 2 sets out the theory, questions, and various hypotheses tested in the research. Section 3 explains the field research methodology. Section 4 presents the findings. Section 5 gives the conclusions and discusses various policy recommendations.

\section{Theory, questions and hypotheses}

The dramatic two-thirds depreciation in the value of the rupiah against the U.S. dollar is the central event of the economic crisis. It led directly to massive business failures, lay-offs and unemployment, bank and loan defaults, scarcity of credit, withdrawal of foreign investment, and the stagnation and decline of most of Indonesia's economic sectors. However, as alluded to above, the consequences of the depreciation are not uniformly bad for all people and enterprises. The consequences of the depreciation diverge fundamentally with respect to degree of access to export income. Those who sell to the export market can get a large windfall profit because a given amount of dollar income during the crisis could (on average) produce a threefold increase in rupiah income. This income, of course, must be balanced against rising production costs as well as the increase in the prices of food and other consumer goods. Conversely, those who lack access to U.S. dollar income through contact with the export market might face stagnant or declining real income possibilities and rising production costs.
These diverging income possibilities are readily evident with respect to the agricultural sector through a review of monthly commodity prices from January 1997 to September 1999 (Figure 1). Beginning in July 1997 the rupiah prices of black pepper, white pepper, cocoa and coffee skyrocketed, reached a peak in mid-1998, and then declined sharply again. These prices then remained level or continued to decline at a slower rate through mid-1999. This contrasts strikingly with the price of rice (IR-36), a non-export crop, which remained relatively level through the crisis. Note, however, that there are export commodities (palm oil, rubber, cinnamon) whose prices did not rise dramatically, and even fell below the food consumer price index. This illustrates a key point. Export commodity prices changed over time not only as a function of the relative value of the rupiah against the US dollar, but also in terms of world price movements, and probably also reflected differences in marketing systems and transport costs. Thus, as will be seen, it is simplistic to just assume that export-oriented farmers have gained and domestic market-oriented farmers have lost. One lesson, however, is that certain export commodity price increases have potentially enabled sizeable windfall profits to farmers.

It is clear from the above that a cogent analysis of how small farmers have fared during Indonesia's economic crisis must examine differential farmer access to export commodity income. Thus in this research project Indonesian small farmers are classified into two broad groupings: (1) those with high export commodity income (hereafter "high ECI" households), defined as those for which agricultural export commodity income is at least half of the total household cash income in a given year; and (2) those with low export commodity income (hereafter "low ECI" households), defined as those for which agricultural export commodity income is less than half the total household cash income in a given year.

The two key research questions presented in the introduction are now elaborated on the basis of this theory and terminology. Specifically:

(1) Wellbeing. What are the implications of high and low access to export commodity income for the wellbeing of small farmers in the midst of the crisis? What are the livelihood adjustments made during the crisis, and how do these adjustments differ in terms of relative access to export commodity income? What kinds of policy interventions might be necessary to help these households maintain a sufficient level of income from environmentally appropriate sources in the midst of the crisis?

(2) Forest-cover consequences. What are the differential effects of the segmentation between high ECI and low ECI households on the quantity and quality of 
Figure 1. Commodity price index in terms of food consumer price index, January 1997 - September 1999.

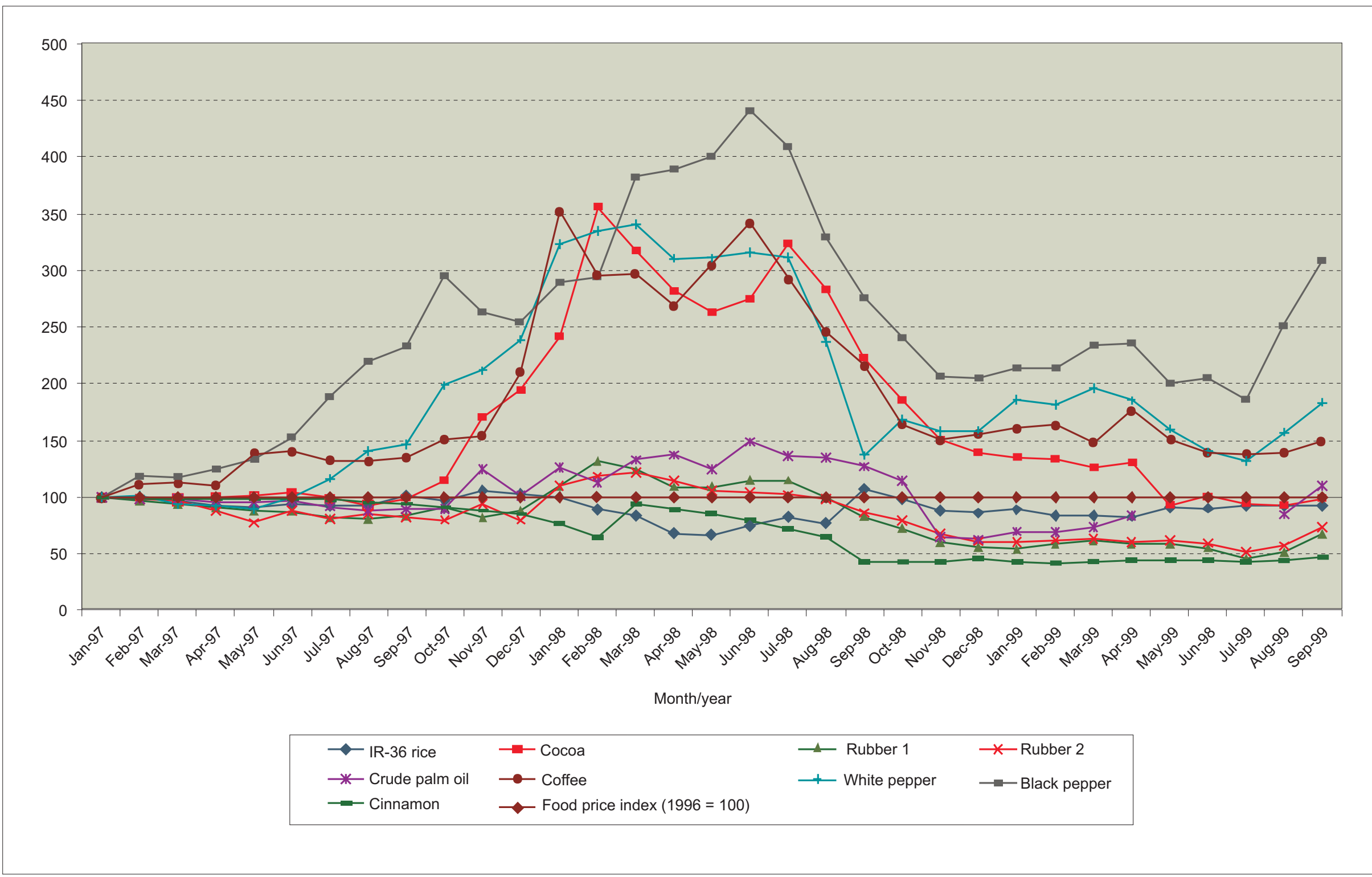


natural forest cover? Specifically, how does the expanding income of high ECI households and the stagnant or declining income of low ECI households affect forest clearing decisions such as fallow period, area and siting of forests cleared, technologies used, and comparative valuation of forests for nonagricultural purposes?

\section{Hypotheses on the issue of wellbeing}

Two hypotheses were formulated on the issue of how the crisis has affected the wellbeing of small farmers in forested areas:

(1) On the basis of visits to our future research sites in 1998, and observing that in some cases cost increases were outpacing income gains, it was concluded that the crisis might have had a larger negative impact than initially expected (Angelsen and Resosudarmo 1999).

(2) On the basis of recent research findings on the effects of economic crisis in Cameroon, we hypothesised that in some forest communities there will be greater reliance on non-timber forest products (NTFPs) as an alternative source of income. This would also be in line with the general thesis that NTFPs can function as a "safety net". The "NTFP-rush" could, nevertheless, lead to an overexploitation of the resources, and therefore might only be a short-term solution.

\section{Hypotheses on the issue of forest clearing}

With regard to the research question on forest clearing, we hypothesised that high ECI households would tend to clear more forest land during the crisis than before the crisis, and that low ECI households would show a wide diversity of responses, ranging from an increased rate of clearing, the same rate of clearing, and a decreased rate of clearing. These assumptions are specified in the four following hypotheses:

(1) Households with high ECI, being better off economically and enabled through family "return migration", reduction of labour allocated to less profitable activities, and/or hiring of labour, are able to clear significantly more forest land than before;

(2) Some low ECI households are worse off economically and clear more forest land than before to compensate for the increased cost of basic commodities.

(3) Some low ECI households are worse off economically, rely more on NTFPs, and clear on average the same amount of forest land as before.

(4) Some low ECI households are worse off economically and clear less forest land than before because members of the household have become part of the labour force in high ECI households.

As part of testing these four hypotheses, the study aimed to discover whether farmers tend to respond to higher agricultural prices (of both export and non-export crops) by expanding their area of cultivated land, or by increasing the intensity of production through better management or more inputs, or both. We foresaw that these outcomes might be influenced by a range of political reform, economic and agronomic factors that include the following:

- the possibility of increased farmer encroachment into protected forest areas resulting from undermined authority of the state and reduced capacity for law enforcement;

- the possibility of crisis-related looting and land claim disputes (if enforcement of property rights is a problem, farmers will be reluctant to clear new land in forests far from their homes);

- the extent to which farmers expect price increases to be permanent (if seen as permanent, then more clearing would follow);

- to what extent farmers are dependent on consumption commodities and to what extent the prices for these have increased (the more they have increased, the greater extensification or intensification will be);

- the gestation period for the relevant crop (a long gestation period implies a smaller extensification response) $;^{8}$

- the degree of labour intensity and transportation costs (if high, farmers will not clear new land far from their houses in areas where forest cover is potentially more dense);

- among the households with high ECI, the rich ones are in a better position to take advantage of the opportunities created, for example, by having sufficient capital to undertake investments and to hire labour.

\section{Methodology}

This section presents information on the methodology used for researching the effect of the crisis on small farmers and the condition of natural forests in the outer islands. The five parts of this section are on: (1) the sample frame and field research locations; (2) the preliminary census of households; (3) the selection of survey respondents, the questions posed in the quantitative survey, and the approaches used in obtaining data; (4) the qualitative survey; and (5) the survey on migration. 


\subsection{Sample frame and field research locations}

A representative random sample survey of small farmer households in natural forest areas was judged to be the most appropriate way to answer and test the central research questions and hypotheses.

The five provinces chosen for the study were Riau/ Jambi, ${ }^{9}$ Lampung, West Kalimantan, East Kalimantan and Central Sulawesi. These provinces were chosen with three criteria in mind. First, we wanted provinces that encompass a wide diversity of export crop types, noting that: rubber production tends to be dominant in Sumatra and West Kalimantan; there is substantial coffee production in Lampung; and cocoa production is heavily concentrated in Central Sulawesi. Second, we wanted to include a diversity of density and age of forest cover, ranging from the relatively abundant and older forests of East Kalimantan and Riau/Jambi, to the relatively sparse and younger secondary forests of Lampung. Third, we wanted to capture a range of experiences with respect to the drought and forest fires of 1997-98. Knowing that effects of the drought and fire might be confounded with the economic effects of the crisis,$^{10}$ we sought to include areas hard-hit by the drought and fires (Lampung and East Kalimantan), as well as those less severely affected (Riau/Jambi) so that we might gain knowledge through the contrast.

The field research was carried out through a random sample survey of 1,050 households -210 households in each of the five provinces. Within each province, 35 households were surveyed in each of six villages. The sample frame is presented in Table 1 and the location of the villages within each of the study provinces is presented in Figure 2. It should be emphasised that we cannot claim representativeness at the level of the province. In the text we will refer to the "study provinces" as a convenient shorthand, but without implying that our data fully represent conditions in those provinces.

Table 1. Sample frame for the study provinces, villages, and households.

\begin{tabular}{lccc}
\hline Province & $\begin{array}{c}\text { Number } \\
\text { of study } \\
\text { villages }\end{array}$ & $\begin{array}{c}\text { Number of } \\
\text { households } \\
\text { in each } \\
\text { village }\end{array}$ & $\begin{array}{c}\text { Number of } \\
\text { households } \\
\text { in each } \\
\text { province }\end{array}$ \\
\hline Riau/Jambi & 6 & 35 & 210 \\
Lampung & 6 & 35 & 210 \\
West Kalimantan & 6 & 35 & 210 \\
East Kalimantan & 6 & 35 & 210 \\
Central Sulawesi & 6 & 35 & 210 \\
\hline Total & 30 & 210 & 1,050 \\
\hline
\end{tabular}

Note that three villages were selected in each of Riau and Jambi.
The criteria for the selection of study villages and an evaluation of the strengths and weaknesses of the sample frame are presented in Appendices 2 and 3.

\subsection{The preliminary census}

A preliminary census of all households in 40 villages (eight in each province) was conducted in February-April 1999. Eight villages were initially chosen in each province so that the best six could be selected for the household survey, and so that two villages in each province could be held in reserve in the event that any of the six selected did not work out.

The purpose of the census was threefold. First, the census served as a means to ensure that the socioeconomic characteristics of the village conformed to the criteria of village selection (see Appendix 2) and to narrow the number of villages within a province from eight to six. Second, the census provided universal (in the sense of village-wide and not simply sample-based) information on key information such as migration, types of farming activities, forest clearing practices, and use of forest resources. Third, the census information served as a basis for stratifying the random selection of household survey respondents. Additional information on the stratification of the census data for selection of the household survey respondents is in Appendix 4.

\subsection{Survey respondents, questions posed and approach}

The quantitative household survey was administered to the head of household and the spouse (in cases where the head of household had a spouse). The survey was conducted from June through August 1999.

The purpose of the household survey was to gather indepth information on a variety of topics from the sample of 35 households in each of the 30 study villages. Among the topics investigated were: (1) basic household information such as the occupations and activities of all household members; (2) changes in perceived levels of living and sources of income in the course of three reference periods measuring change in the year prior to the crisis and the first two years of the crisis (see specification below); (3) levels of living as measured by the condition of the house, asset ownership, changes in savings practices and credit dependence, and land ownership; (4) changes in agricultural practices in the course of the three reference years; (5) changes in forest clearing practices in the course of the three reference years; and (6) changes in the gathering and capture of forest products in the course of the three reference years. 
Figure 2. Map of Indonesia showing the research provinces and villages.

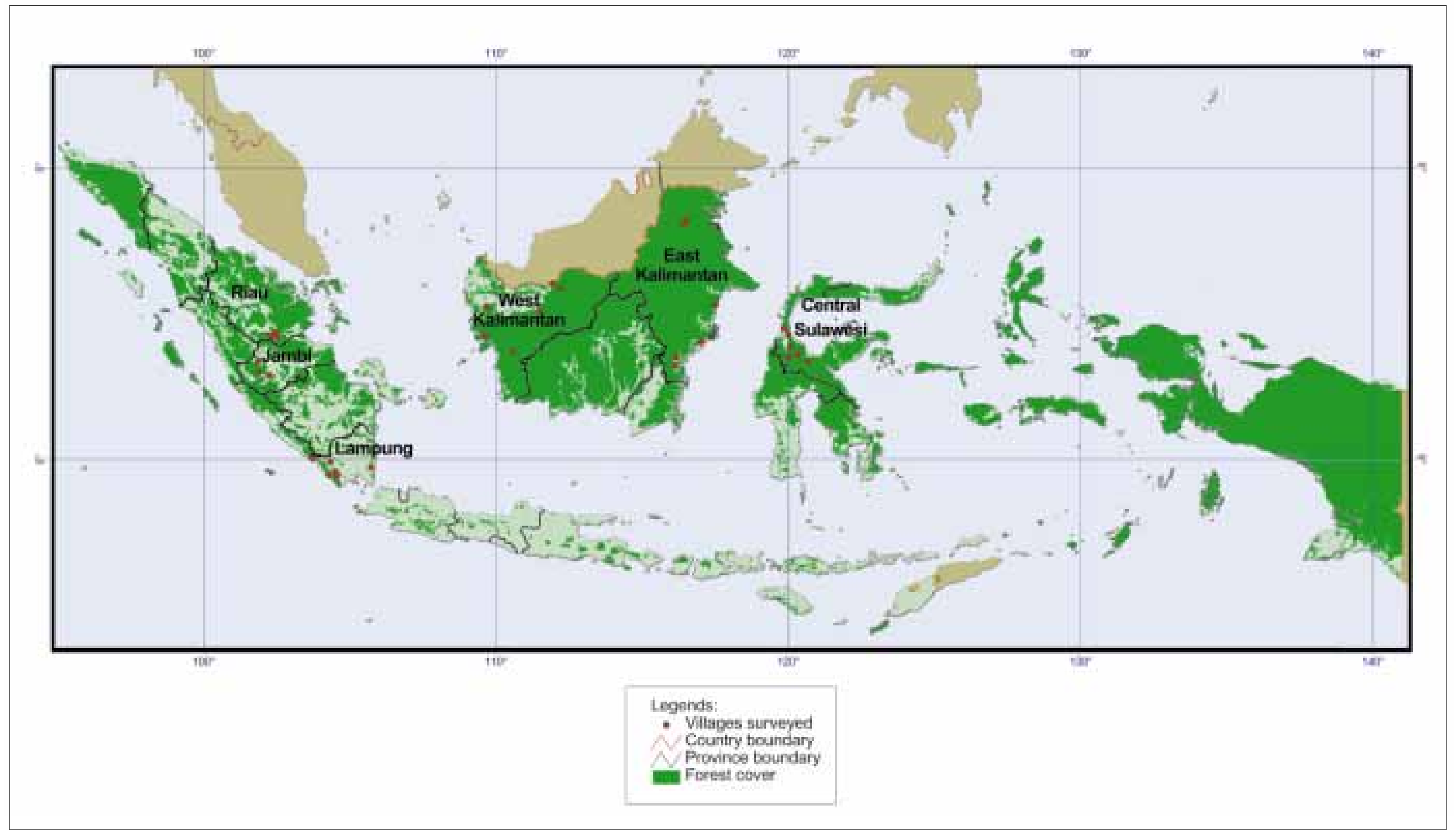


The survey approach relied to a great extent on the ability of respondents to recall household information in each of three clearly specified reference periods. In this way, household status prior to and during the crisis could be compared. These three periods are:

Period 11 July 1996 through 30 June 1997, the oneyear period directly before the onset of the economic crisis;

Period 21 July 1997 through 30 June 1998, the first year of the economic crisis, and also the span of time in which the worst effects of the drought and forest fires occurred;

Period 31 July 1998 through 30 June 1999, the second year of the economic crisis, and the 12 -month period before the date of the household survey interview.

From a methodological perspective, it was important to distinguish period 1 from period 2 and period 3 in order to understand the status of the household and its activities prior to the crisis and during the crisis. But it was just as important to distinguish period 2 from period 3, given that many households were strongly affected by the drought and fires in period 2, and much less so in period 3 . Figure 3 describes the three reference years against the backdrop of the calendar year. might influence forest clearing practices. This topic, however, could not be researched through the quantitative household survey because, as noted above, respondents were limited to those who had lived in the study villages continuously since the beginning of the year prior to the onset of the crisis. This in effect excludes from the quantitative survey households that have migrated to the study villages because of the crisis. For this reason, we conducted a small survey of all heads of household enumerated in the household census who had migrated to the study villages since the beginning of the crisis in mid-1997. This survey posed questions on the place of origin prior to migration, the type of work at the point of origin, and the reasons (both of the "push" and "pull" type) for migration.

\section{Findings}

The research findings are presented in five parts on: (1) general information on study household characteristics; (2) the effects of the crisis on the economic wellbeing of small farmers; (3) the effects of the crisis on forest clearing practices; (4) summary of the major findings; and (5) unresolved questions.

Figure 3. Reference years in the recall approach.

\begin{tabular}{|c|c|c|c|c|c|c|c|}
\hline \multicolumn{2}{|c|}{1996} & \multicolumn{2}{|c|}{1997} & \multicolumn{2}{|c|}{1998} & \multicolumn{2}{|c|}{1999} \\
\hline \multirow[t]{3}{*}{ Jan. } & Dec. & Jan. & Dec. & Jan. & Dec. & Jan. & \multirow[t]{3}{*}{ Dec. } \\
\hline & \multicolumn{2}{|c|}{$\begin{array}{c}\text { Period } 1 \\
\text { July } 96 \text { - June } 97\end{array}$} & \multicolumn{2}{|c|}{$\begin{array}{c}\text { Period } 2 \\
\text { July } 97 \text { - June } 98\end{array}$} & \multicolumn{2}{|c|}{$\begin{array}{c}\text { Period } 3 \\
\text { July } 98 \text { - June } 99\end{array}$} & \\
\hline & \multicolumn{2}{|c|}{$\begin{array}{c}\text { Year prior to beginning } \\
\text { of crisis }\end{array}$} & \multicolumn{2}{|c|}{$\begin{array}{l}\text { First crisis year. } \\
\text { Year of drought and fires }\end{array}$} & \multicolumn{2}{|c|}{$\begin{array}{l}\text { Second crisis year. } \\
12 \text {-month period before } \\
\text { interview. }\end{array}$} & \\
\hline
\end{tabular}

\subsection{Qualitative survey}

A follow-up qualitative, semi-structured interview was conducted in September-October 1999, after implementation of the quantitative household survey. The interview was conducted with 8-16 villagers judged to be competent key informants. The purposes of the qualitative survey were to gain deeper understanding of information obtained through the quantitative household survey and to complete the testing of the hypotheses.

\subsection{Survey on migration}

The hypotheses on changes in forest clearing, explained above, assume that changes in the size of the household labour force, brought about by crisis-related migration,

\subsection{Study household characteristics}

Information on crops produced and on degree of export crop dependence of study households is presented first to serve as background for findings discussed in the subsequent sections.

By far the dominant crop, measured as the largest cash income-producing crop within a household in period 3 , is rubber, accounting for $276(32 \%)$ of the 870 households for which data were available (Figure 4). In second and third places, respectively, are coffee (161 households, 19\%) and cocoa (139 households, 16\%). These three export crops comprise $66 \%$ of the total, and all export crop types (including these three and pepper, oil palm and cinnamon) comprise 683 households or $79 \%$ of the total. 
Figure 4. Study households by primary crops produced in 1998-99, all provinces.

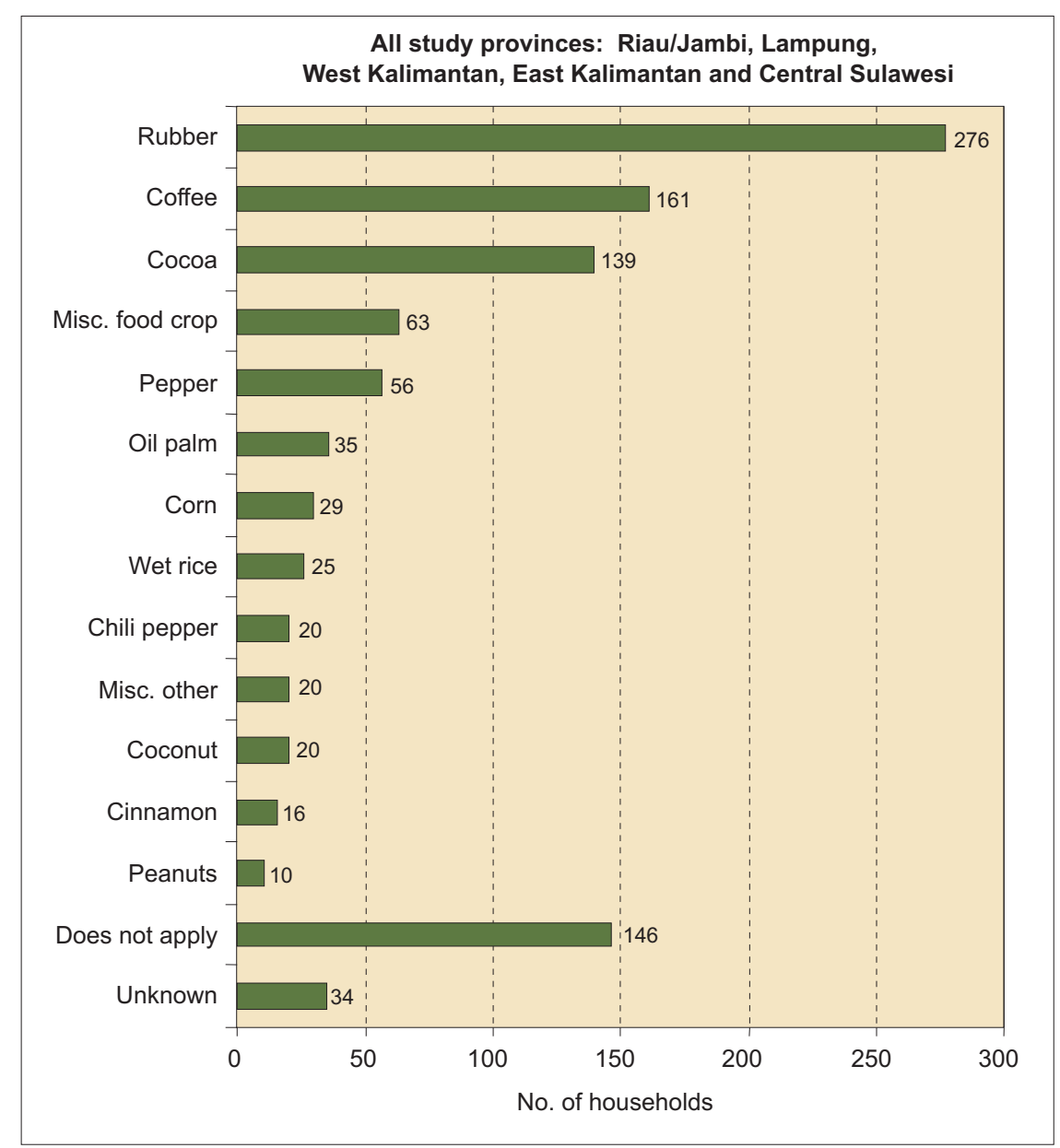

The provinces are sharply differentiated by crop type. The study households of Riau/Jambi and West Kalimantan are overwhelmingly dominated by rubber production, and rubber is not found in the other three provinces. The study households of Lampung are dominated by coffee production. The distinctive feature of the East Kalimantan study households is relatively equal distribution among four main commodities: cocoa, coffee, oil palm, and pepper. Cocoa is the main cash crop in the Central Sulawesi study households, but various kinds of food crops are produced as well (Figure 5).

Study households were classified by the proportion of gross cash income coming from agricultural export commodities in period 3 . The study provinces are sharply differentiated by degree of dependence on export commodities (Figure 6). East Kalimantan shows the highest level of dependence with $71 \%$ of study households getting more than half of their income from export commodities. Riau/Jambi rates second at 57\%, West Kalimantan third at $35.9 \%$, Lampung fourth at $35.7 \%$, and Central Sulawesi last at 27.4\%.

\subsection{Effects on wellbeing of small farmers}

\section{General findings on wellbeing}

Respondents of the survey where asked to rate the wellbeing of their household in the second year of the crisis (period 3, 1998-99) in comparison to the year before the crisis (period 1, 1996-97). Four closed-option responses were allowed: "better off;" "the same;" "worse off;" and "don't know". Six-hundred and fiftynine respondents (63\%) said they were worse off; 188 (18\%) said their situation was the same; 199 (19\%) said they were better off; and $4(0 \%)$ did not know (Figure 7). Thus a first and key finding is that almost two out of every three farm households viewed themselves as worse off during the crisis than before the crisis. This contrasts with the common belief that farmers were doing reasonably well during the crisis, and it is in line with our observations during the preparatory field visits (Angelsen and Resosudarmo 1999). 
Figure 5 Study households by primary crop produced in 1998-99 and by study provinces.

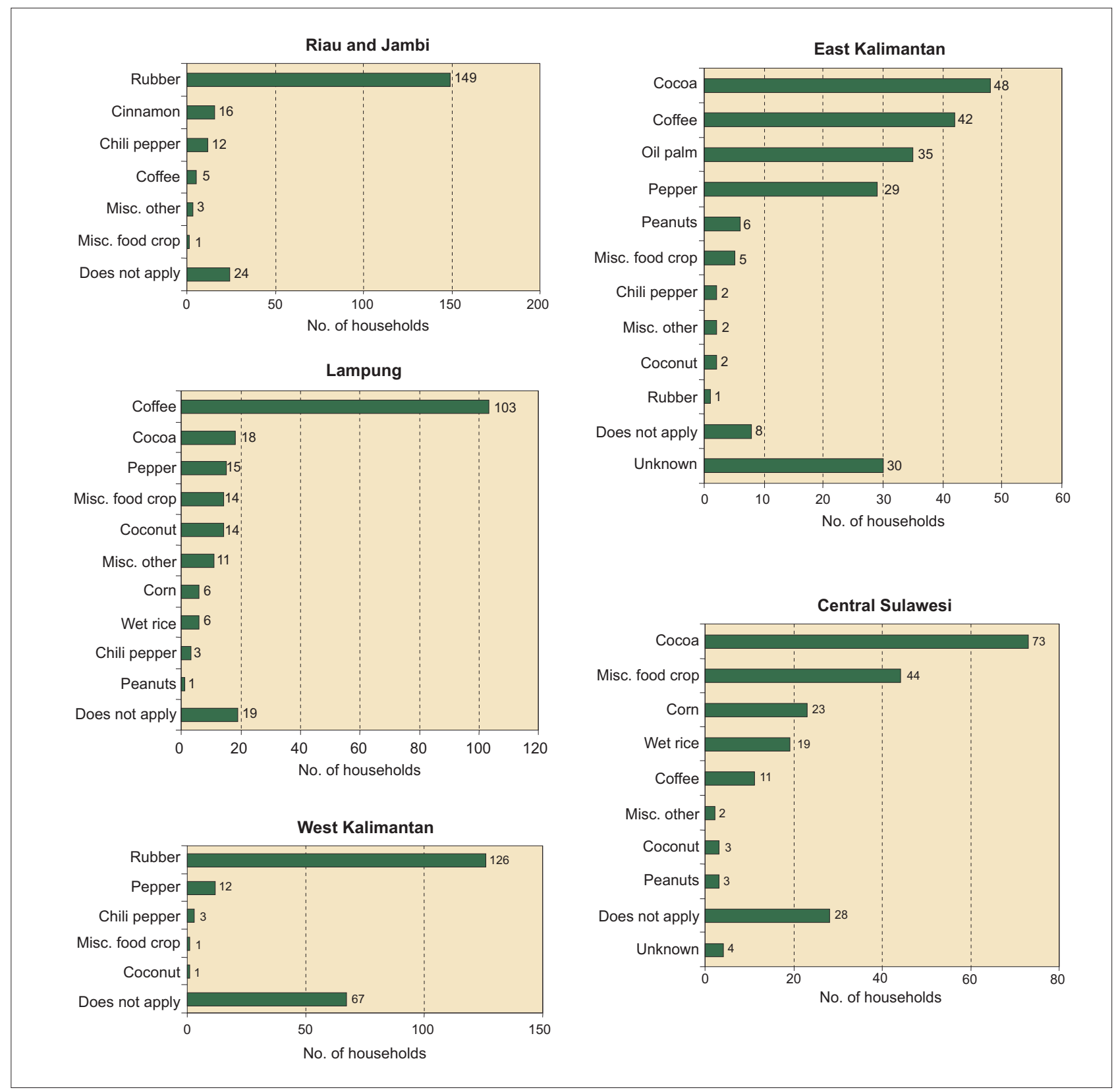

Figure 6. Degree of dependence of households on export commodity income in 1998-99.

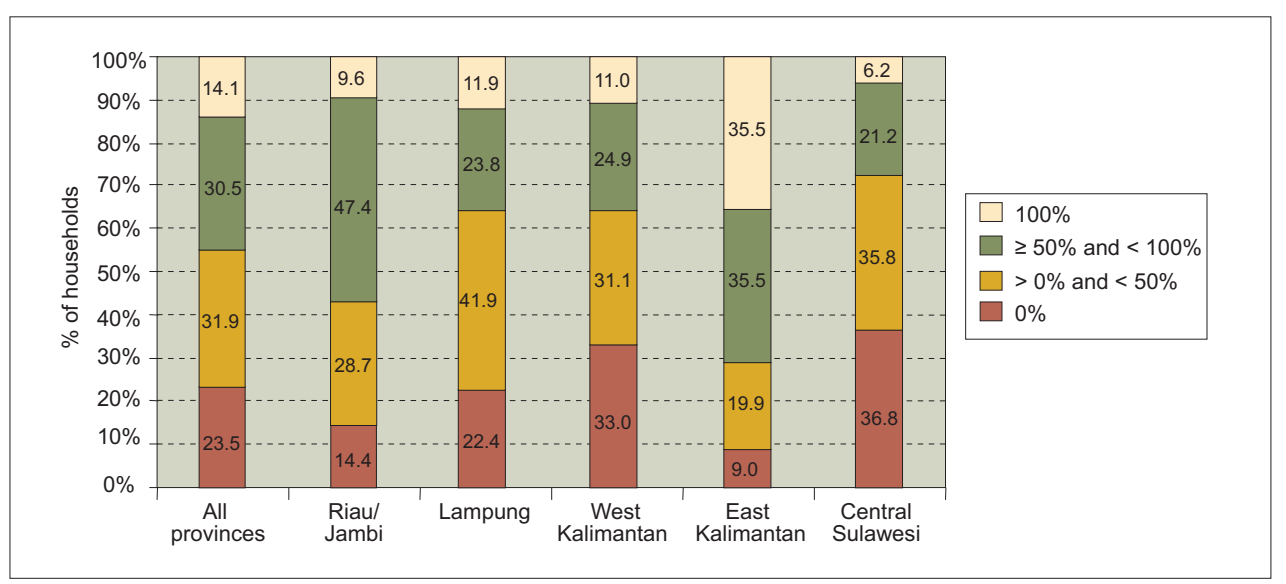


Figure 7. View of respondents on their status in period 3 (1998-1999) as compared to period 1 (1996-1997).

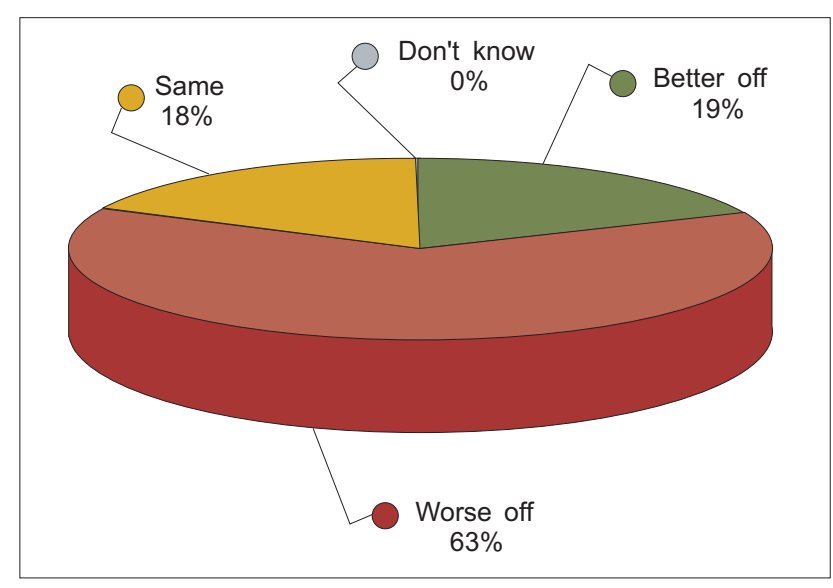

The findings are sharply differentiated by study province. East Kalimantan and Lampung were the only two study provinces where most households avoided a bad outcome. East Kalimantan fared the best, with $59 \%$ of households claiming to be either better off or the same; Lampung was in second place with 51\%; West Kalimantan was third with 30\%; Central Sulawesi was fourth with $27 \%$; and Riau/Jambi was last with 18\% (Figure 8).

The findings are surprising in three senses. First, East Kalimantan fared best among the five provinces in terms of perceived household wellbeing, in spite of the fact that it is one of the provinces of Indonesia known to have been worst hit by the drought and fires of 1997-98 (see discussion below). Second, Lampung appears to have fared well, and Riau/Jambi appears to have fared quite badly, in spite of the fact that a Central Bureau of Statistics study (BPS 1999:17) found exactly the opposite. ${ }^{11}$ It should be noted, however, that the BPS study is based on results in the first year of the crisis, whereas the results of this study are based on the second year. Moreover, the populations sampled are different. Third, it is somewhat surprising that Central Sulawesi fared poorly because it has acquired a reputation in the print media for doing well in the midst of the crisis, largely because of the presumed windfall benefits of cocoa production.

\section{Relationship of wellbeing to export income and particular crops}

Gross household income was measured for the three periods of the study. These data are cross-classified with a binary variable indicating degree of export commodity income (ECI) (Table 2). Those with "high" ECI got half or more of their income in the corresponding period from this source, whereas "low" ECI got less than half their income from this source. The results show that in the year before the crisis (period 1), low-ECI households had gross income that was about 50\% higher than high-ECI households, and the difference was statistically significant. In the first year of the crisis (period 2), gross income grew rapidly in both categories. The income of high-ECI households surpassed that of low-ECI households, but not at a statistically significant level. In the second year of the crisis (period 3), the gross income of high-ECI households continued to increase slightly while that of low-ECI households decreased. The gap between high- and low-ECI incomes was wider than in period 2 (but still not at a statistically significant level).

Figure 8. Classification of study households by crisis experience and study provinces.

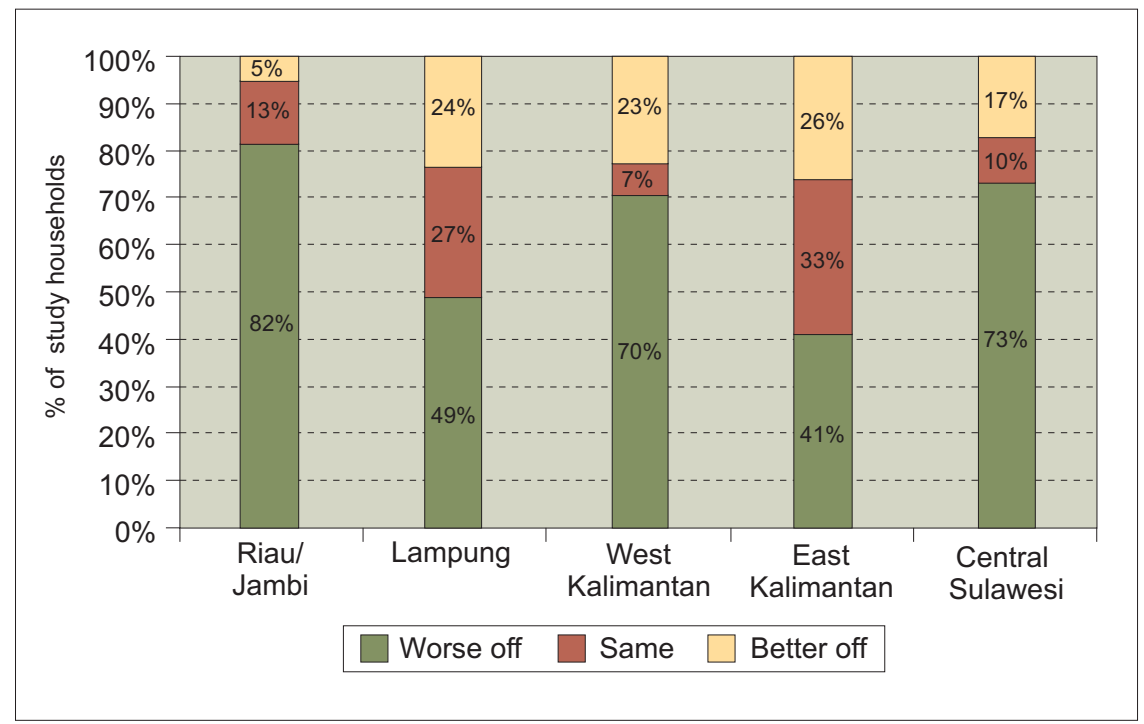


Table 2. Independent means test of estimated total household income, differentiated by high- and no/low$\mathrm{ECl}$, pre-crisis and crisis.

\begin{tabular}{|c|c|c|c|c|c|}
\hline Time period & $\begin{array}{c}\mathrm{ECl} \text { income as } \\
\text { proportion of } \\
\text { total }\end{array}$ & $\begin{array}{c}\text { Number of } \\
\text { households and } \\
\text { percent of total }\end{array}$ & $\begin{array}{c}\text { Mean total } \\
\text { household } \\
\text { income (Rp.) }\end{array}$ & $\begin{array}{l}\text { Significance } \\
\text { (equality of }^{\text {variances) }}\end{array}$ & $\begin{array}{c}\text { Significance } \\
\text { (2-tailed equality } \\
\text { of means) }\end{array}$ \\
\hline \multirow{2}{*}{$\begin{array}{l}\text { 1996-97 } \\
\text { (pre-crisis) }\end{array}$} & $\geq 50 \%$ & $457(45.8 \%)$ & $2,450,597$ & \multirow{2}{*}{.000} & \multirow{2}{*}{.000} \\
\hline & $<50 \%$ & $540(54.2 \%)$ & $3,607,403$ & & \\
\hline \multirow{2}{*}{$\begin{array}{l}1997-98 \\
\text { (crisis) }\end{array}$} & $\geq 50 \%$ & $493(50.8 \%)$ & $5,863,704$ & \multirow{2}{*}{.226} & \multirow{2}{*}{.556} \\
\hline & $<50 \%$ & $478(49.2 \%)$ & $5,457,814$ & & \\
\hline 1998-99 & $\geq 50 \%$ & $442(44.8 \%)$ & $6,068,926$ & \multirow{2}{*}{.000} & \multirow{2}{*}{.107} \\
\hline (crisis) & $<50 \%$ & $545(55.2 \%)$ & $5,161,072$ & & \\
\hline
\end{tabular}

$\mathrm{a}=$ equal variances assumed.

Data on the views of survey respondents on their wellbeing (see Figure 7) were cross-classified with a fourlevel variable on the degree of income from export commodities in period 3. The results (Table 3) demonstrate a strong relationship between the level of export commodity income and the perceived level of wellbeing of the respondents. Among those who get all of their income from export commodities, 33\% view themselves as better off during the second year of the crisis and $46 \%$ view themselves as worse off. Conversely, among those who get no income from export commodities, only $13 \%$ claim to be better off and $71 \%$ claim to be worse off.

Table 3. Perception of household wellbeing during 199899 as compared to 1996-97, by level of export commodity income in 1998-99.

\begin{tabular}{|c|c|c|c|c|}
\hline \multirow[t]{2}{*}{$\begin{array}{l}\text { Degree of } \\
\text { income } \\
\text { from } \mathrm{ECl}\end{array}$} & \multicolumn{3}{|c|}{$\begin{array}{l}\text { Perception of household } \\
\text { wellbeing during 1998-99 } \\
\text { as compared to } 1996-97\end{array}$} & \multirow[t]{2}{*}{ Total } \\
\hline & Worse off & Same & Better off & \\
\hline $100 \%$ & $\begin{array}{r}64 \\
(46.4 \%)\end{array}$ & $\begin{array}{r}29 \\
(21 \%)\end{array}$ & $\begin{array}{r}45 \\
(32.6 \%)\end{array}$ & $\begin{array}{r}138 \\
(100 \%)\end{array}$ \\
\hline$\geq 50 \%$ and $<100 \%$ & $\begin{array}{r}192 \\
(63.8 \%)\end{array}$ & $\begin{array}{r}53 \\
(17.6 \%)\end{array}$ & $\begin{array}{r}56 \\
(18.5 \%)\end{array}$ & $\begin{array}{r}301 \\
(100 \%)\end{array}$ \\
\hline$>0 \%$ and $<50 \%$ & $\begin{array}{r}201 \\
(64.4 \%)\end{array}$ & $\begin{array}{r}50 \\
(16.0 \%)\end{array}$ & $\begin{array}{r}61 \\
(19.6 \%)\end{array}$ & $\begin{array}{r}312 \\
(100 \%)\end{array}$ \\
\hline $0 \%$ & $\begin{array}{r}165 \\
(71.1 \%)\end{array}$ & $\begin{array}{r}36 \\
(15.5 \%)\end{array}$ & $\begin{array}{r}31 \\
(13.4 \%)\end{array}$ & $\begin{array}{r}232 \\
(100 \%)\end{array}$ \\
\hline Total & $\begin{array}{r}622 \\
(63.3 \%)\end{array}$ & $\begin{array}{r}168 \\
(17.1 \%)\end{array}$ & $\begin{array}{r}193 \\
(19.6 \%)\end{array}$ & $\begin{array}{r}983 \\
(100 \%)\end{array}$ \\
\hline
\end{tabular}

The total in the second, third and fourth coloumns are lower than the well being figures in page 9 and 14 because these variables were combined/crossclassified with $\mathrm{ECl}$ variables.

The study households were classified by their main cashproducing crop in period 3 and their perception of household wellbeing in period 3 as compared to period 1. The results, shown in Figure 9, rank the crops left to right, from most to least successful. The most successful is pepper, with almost three-quarters of those reliant on this crop experiencing improved household wellbeing in the midst of the crisis. The worst is chili pepper, with approximately $5 \%$ experiencing improved wellbeing. Note that the numbers of producers in each crop category has important implications. The fact that rubber producers fared poorly is significant because it represents about a third of study households. Conversely, the good performance of coconut is relatively insignificant because the number of producers among study households is so small (20, or about $2 \%$ of the total).

Note that the potential for specific crops to promote household wellbeing is generally closely related to the price movements of these crops as presented in Figure 1. For example pepper ranks highest in Figure 9 and it is the crop that shows the highest overall price increment for the period January 1997 to September 1999 (Figure 1). Conversely, rubber ranks among the lowest commodities in Figure 9 in terms of contributing to household wellbeing and, correspondingly, its price shows a net decline in the period January 1997 to September 1999 (Figure 1). Cocoa is an important and instructive intermediate case. Like pepper, cocoa experienced a spectacular growth in price from mid-1997 to mid-1998 (Figure 1). Why then did cocoa farmers tend to perceive themselves as worse off in the second year of the crisis (1998-99) compared to the year before the crisis (Figure 9)? The reason appears to be that the price decline of cocoa in 1998-99 was far more precipitous than that of pepper, even going below the food price index in mid-1999 (Figure 1).

\section{The crisis in relation to the drought and fires of 1997-98}

The survey respondents were asked whether their household was affected by the drought and fires that ravaged many parts of Indonesia from mid-1997 to mid1998. The answers, disaggregated by study province, show a wide diversity of responses. Hardest hit by far was East Kalimantan, with $100 \%$ of study households reporting an impact from the drought and fires. About three-quarters of study households in each of Lampung and Central Sulawesi, and almost half the households in West Kalimantan said they felt the effect of the drought 
Figure 9. Classification of study households according to perceived crisis experience and main income-producing crop in 1998-99.

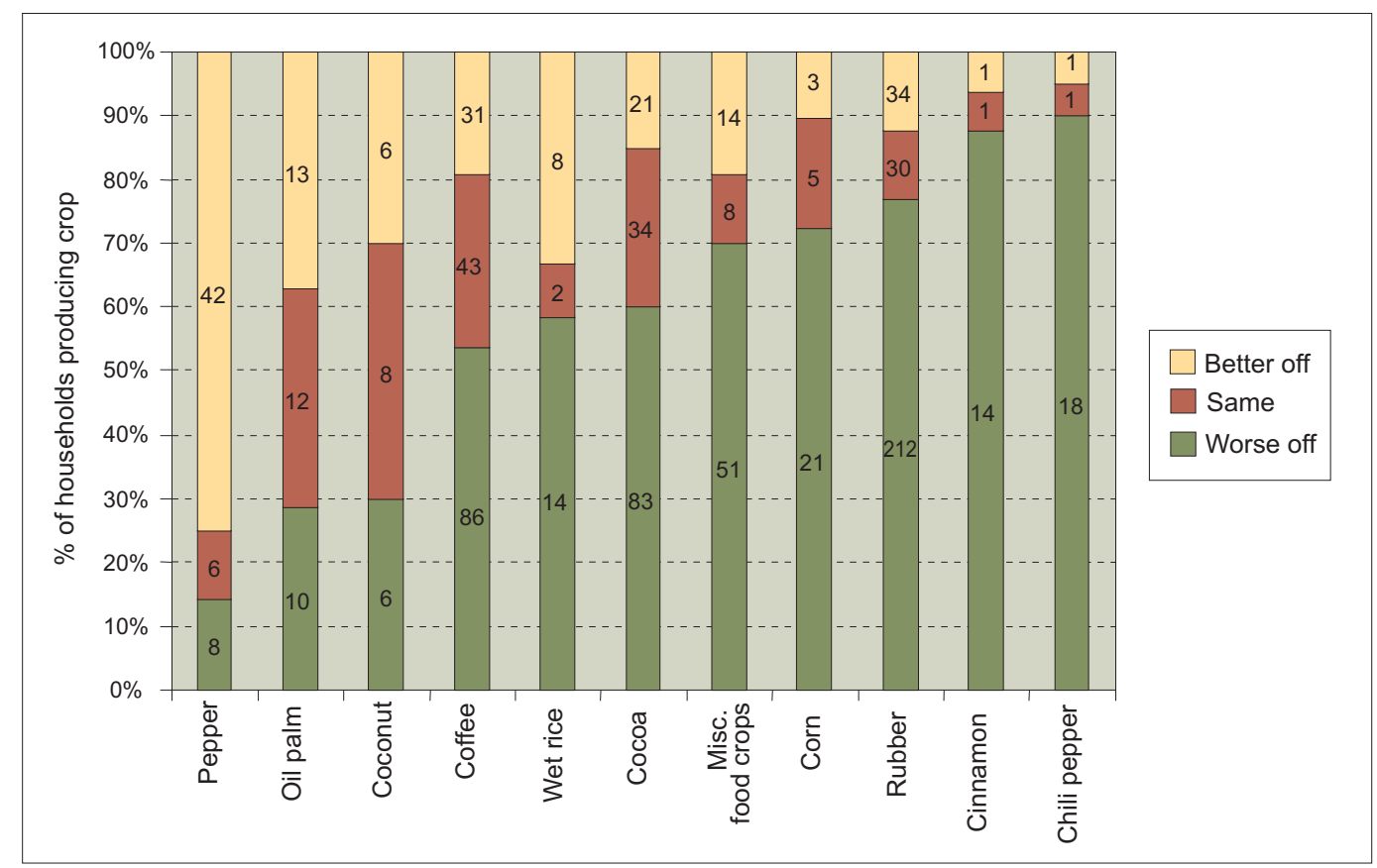

and fires. Least badly hit was Riau/Jambi with only a third of households saying there was such an effect (Table 4).

Table 4. Respondent perception of whether the 1997-98 drought and fires influences them, by study provinces.

\begin{tabular}{lrrr}
\hline Province & $\begin{array}{c}\text { Was there an influence of the } \\
\text { 1997-98 drought and forest fires } \\
\text { on this household? }\end{array}$ & \\
\cline { 2 - 3 } & \multicolumn{1}{c}{ Yes } & Total \\
\cline { 2 - 3 } Riau/Jambi & 73 & 137 & \\
Lampung & $(34.8 \%)$ & $(65.2 \%)$ & $(100 \%)$ \\
West Kalimantan & 149 & 44 & 193 \\
& $(77.2 \%)$ & $(22.8 \%)$ & $(100 \%)$ \\
East Kalimantan & 95 & 115 & 210 \\
& $(45.2 \%)$ & $(54.8 \%)$ & $(100 \%)$ \\
Central Sulawesi & 210 & 0 & 210 \\
& $(100.0 \%)$ & $(0 \%)$ & $(100 \%)$ \\
Total & 150 & 59 & 209 \\
& $(71.8 \%)$ & $(28.2 \%)$ & $(100 \%)$ \\
\hline
\end{tabular}

The 371 respondents (35\% of total) that experienced negative effects from both the economic crisis and the drought/fires were asked to rate which of the two phenomena had a worse effect on their household. The results validate the assumption that it is important to distinguish between the two phenomena in trying to assess the effects of the economic crisis. At the aggregate level,
$41.5 \%$ said the economic crisis was worse, $30.5 \%$ said the drought and fires were worse, and $28.0 \%$ said the two were the same. There is a huge disparity among the study provinces with, at one extreme, $79.7 \%$ of respondents in West Kalimantan saying the economic crisis was worse, and at the other extreme, only $6.4 \%$ of respondents in East Kalimantan saying the crisis was worse (Table 5).

Table 5. Respondent perception of whether the economic crisis or the 1997-98 drought and fires had a worse effect, by study provinces.

\begin{tabular}{lrrrr}
\hline Province & \multicolumn{2}{c}{$\begin{array}{l}\text { Which had a worse influence on } \\
\text { the wellbeing of this household: } \\
\text { the economic crisis, or the } \\
\text { drought/fires of 1997-98? }\end{array}$} & Total \\
\cline { 2 - 4 } & $\begin{array}{c}\text { Economic } \\
\text { crisis }\end{array}$ & $\begin{array}{l}\text { Both were } \\
\text { the same }\end{array}$ & $\begin{array}{l}\text { Drought } \\
\text { and fires }\end{array}$ & \\
\hline Riau/Jambi & 36 & 17 & 10 & 63 \\
Lampung & $(57.1 \%)$ & $(27.0 \%)$ & $(15.9 \%)$ & $(100 \%)$ \\
West Kalimantan & 14 & 17 & 26 & 57 \\
& $(24.6 \%)$ & $(29.8 \%)$ & $(45.6 \%)$ & $(100 \%)$ \\
East Kalimantan & 51 & 10 & 3 & 64 \\
Central Sulawesi & $(79.7 \%)$ & $(15.6 \%)$ & $(4.7 \%)$ & $(100 \%)$ \\
& $(44.4 \%)$ & $(43.6 \%)$ & $(50.0 \%)$ & $(100 \%)$ \\
Total & 48 & 26 & 35 & 109 \\
& 154 & 104 & 113 & 371 \\
& $(41.5 \%)$ & $(28.0 \%)$ & $(30.5 \%)$ & $(100 \%)$ \\
\hline
\end{tabular}




\section{General adjustments to the effects of the crisis}

The 659 respondents (63\% of total) who said they were worse off in period 3 than in period 1 were asked how they responded to the difficulties posed by the crisis. They were read a list of possible responses to the crisis and were asked to state whether the responses applied to their situation. (It is assumed the households adjusted to the crisis in a variety of ways, so multiple answers for a given household were expected.) They were also asked to state ways they faced the difficulties that were not included in the list (Figure 10). Most respondents (more than half) adjusted to the negative effects of the crisis by working harder or working longer hours. About a third of respondents adjusted to the crisis by reducing household expenditures, by finding a new or additional source of income, or by increasing the area of land that they cultivate. About a quarter of households adjusted by cultivating an additional crop or crops, or by depending on and in some cases exhausting their savings. The answers are disaggregated by high and low (or no) dependence on export commodity income in period 3 . The low ECI households have a higher rate of response than high ECI households in all of the response categories.

The 199 respondents (19\% of total) who said they were better off in period 3 than in period 1 were asked how they used their extra income. They were read a list of possible uses of extra income and were asked to state whether the responses applied to their situation. (As with the question on adjustment to difficulties, multiple answers for a given household were expected.) They were also asked to state ways they used extra income that were not included in the list. The responses are summarised in Figure 11. More than half of these households were able to increase their savings or establish

Figure 10. How did households perceiving themselves as worse off cope?

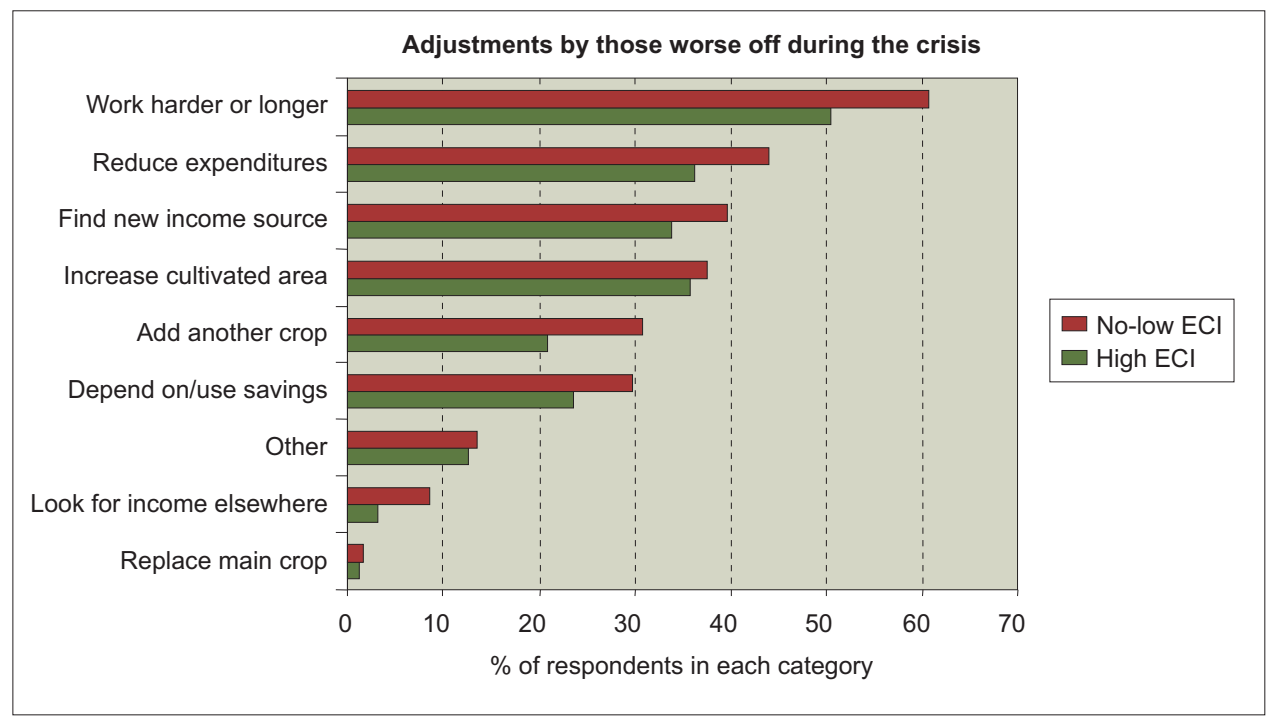

Figure 11. How did households perceiving themselves as better off use their extra income?

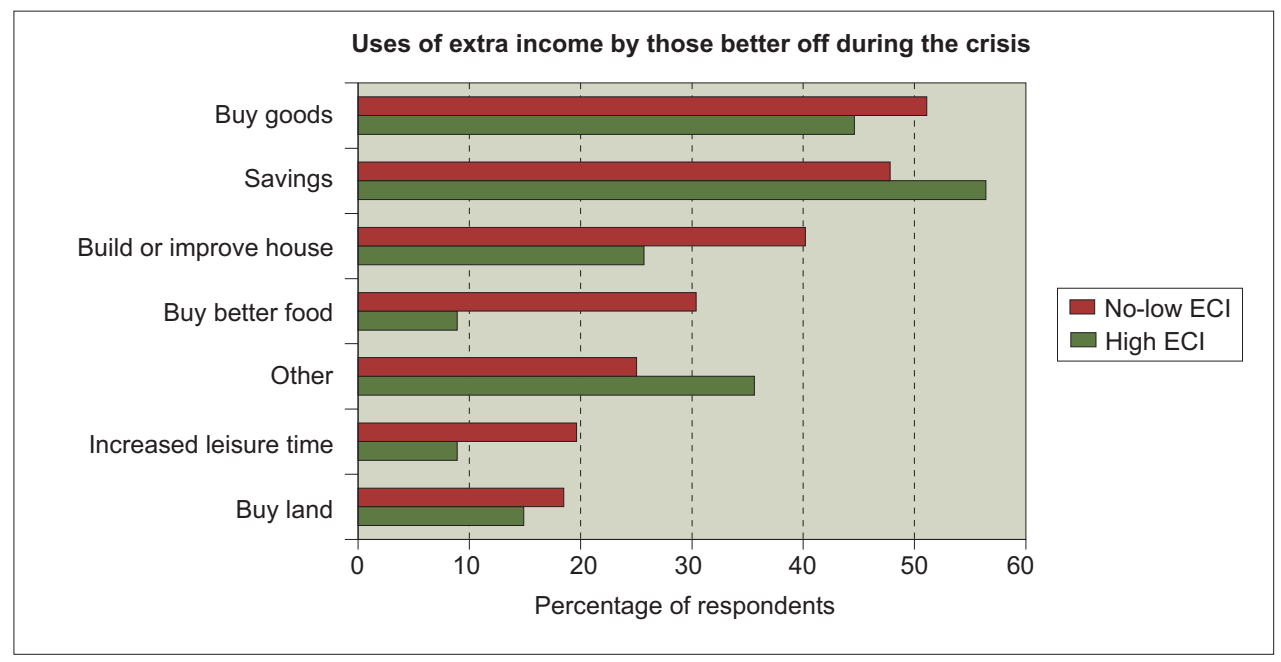


savings if they did not have savings before. Just below half were able to increase purchases of household goods, and about a third were able to build a house or make housing improvements. About one sixth of the respondents were able to buy land, buy higher quality food, and increase their leisure time. Disaggregation of the responses by high and low ECI households in period 3 shows, interestingly, low-ECI households tend to have a higher response rate than high-ECI households. An exception is that high-ECI households have a somewhat higher tendency to increase their savings.

\section{Adjustment in terms of savings and government aid}

Overall, there is a very strong relationship between respondent perceptions of wellbeing during the crisis and their ability to save. The 508 households that were able to save money at some point in the history of the household were asked if they were able to save more money at the time of the interview than they could during the year before the onset of the crisis. The great majority $(89.5 \%)$ of those who claimed they were worse off said they were unable to save as much during the crisis. The majority (74.8\%) of those who claimed they were better off said they were able to save more money during the crisis (Table 6).

Table 6. Relationship between crisis experience and ability to save.

\begin{tabular}{|c|c|c|c|c|}
\hline \multirow{2}{*}{$\begin{array}{l}\text { Respondent } \\
\text { perception of } \\
\text { wellbeing of } \\
\text { household in } \\
1998-99 \text { in } \\
\text { comparison } \\
\text { to } 1996-97\end{array}$} & \multicolumn{3}{|c|}{$\begin{array}{l}\text { Is the household able to save } \\
\text { more money now than it did in the } \\
\text { year before the beginning of the } \\
\text { economic crisis? }\end{array}$} & \multirow[t]{2}{*}{ Total } \\
\hline & Yes & $\begin{array}{c}\text { Same as } \\
\text { before }\end{array}$ & No & \\
\hline Worse off & $\begin{array}{r}21 \\
(6.9 \%)\end{array}$ & $\begin{array}{r}11 \\
(3.6 \%)\end{array}$ & $\begin{array}{r}274 \\
(89.5 \%)\end{array}$ & $\begin{array}{r}306 \\
(100 \%)\end{array}$ \\
\hline Same & $\begin{array}{r}12 \\
(19.0 \%)\end{array}$ & $\begin{array}{r}8 \\
(12.7 \%)\end{array}$ & $\begin{array}{r}43 \\
(68.3 \%)\end{array}$ & $\begin{array}{r}63 \\
(100 \%)\end{array}$ \\
\hline Better off & $\begin{array}{r}104 \\
(74.8 \%)\end{array}$ & $\begin{array}{r}11 \\
(7.9 \%)\end{array}$ & $\begin{array}{r}24 \\
(17.3 \%)\end{array}$ & $\begin{array}{r}139 \\
(100 \%)\end{array}$ \\
\hline Total & $\begin{array}{r}137 \\
(27.0 \%)\end{array}$ & $\begin{array}{r}30 \\
(5.9 \%)\end{array}$ & $\begin{array}{r}341 \\
(67.1 \%)\end{array}$ & $\begin{array}{r}508 \\
(100 \%)\end{array}$ \\
\hline
\end{tabular}

Making use of government aid is potentially an important way to cope with the crisis. There are some indications that government aid (defined in the study as agricultural credit and subsidies for rice, fertilisers or insecticide) was assigned appropriately to those most in need. Table 7 shows that those perceiving themselves as worse off during the crisis received aid at the highest rate $(70.3 \%)$, followed by those perceiving their status as the same $(59.6 \%)$, and by those who perceiving themselves as better off $(56.8 \%)$. The differences are significant at the
.05 level when chi-square comparisons are made between the "worse off" and "better off" categories, and between the "worse off" and "same" categories. It is appropriate to ask why those perceiving themselves as better off or as having no status change received government aid. It is possible, however, that this is not a misallocation of government resources. The provision of government aid may have ameliorated the crisis experience for some households, allowing them to change their perceived status from "worse off" to "same" or even "better off".

Table 7. Relationship between perceived crisis experience and receiving government aid during the crisis.

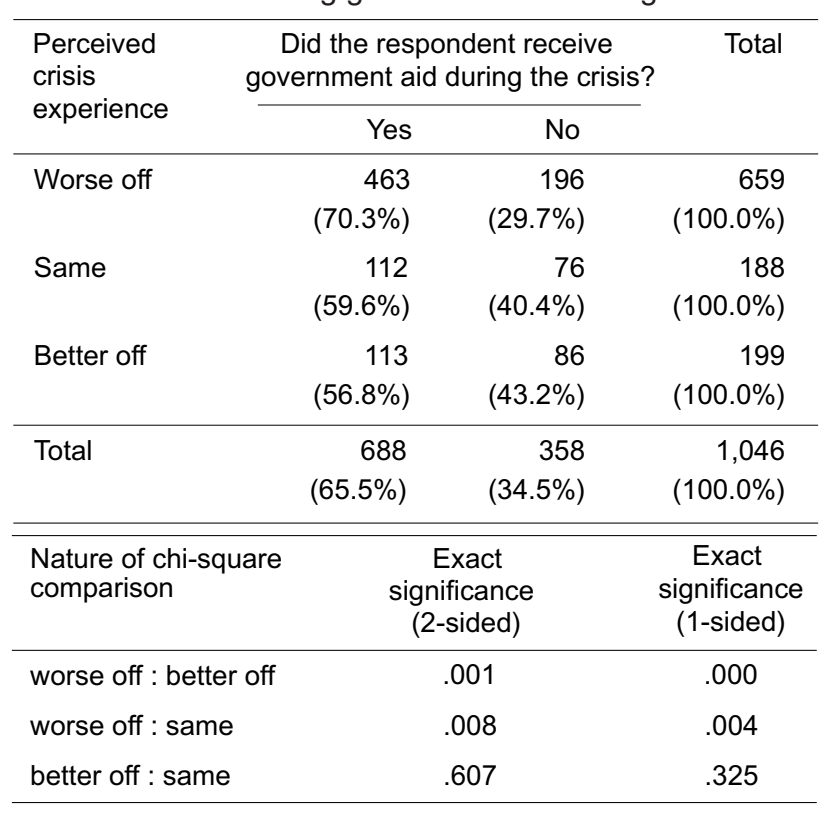

The respondents were asked to state the amount and value of government aid they received in periods 1, 2 and 3 . Table 8 summarises data on the value of government aid received, disaggregating them by those who perceive themselves as better or worse off in period 3, and by highand low-ECI households in period 3. Those who perceive themselves as better off received slightly more government aid, on average, than those who perceive themselves as worse off, though the difference is not significant. High-ECI households got about $50 \%$ more government aid than low ECI households, and the difference is significant. For two reasons, it would not be appropriate to conclude that this amounts to a misallocation of government aid (even though it is possible this happened). First, as above, it is possible that government aid helped ameliorate the crisis experience for some households; it may also have helped some to achieve high-ECI status. Second, high-ECI households tended to have a significantly lower level of household income before the crisis (Table 2) so improvement of their status is not necessarily an undesirable outcome. 
Table 8. Independent means test comparison of level of government aid received by those who perceive themselves as better and worse off during the crisis, and by those with high and no/low ECl.

\begin{tabular}{|c|c|c|c|c|}
\hline $\begin{array}{l}\text { Category of } \\
\text { comparison }\end{array}$ & $\begin{array}{l}\text { Mean } \\
\text { (Rp.) }\end{array}$ & $\mathrm{N}$ & $\begin{array}{l}\text { Significance } \\
\text { (equality of } \\
\text { variance) }\end{array}$ & $\begin{array}{l}\text { Significance } \\
\text { (2-tailed } \\
\text { equality } \\
\text { of means) }\end{array}$ \\
\hline $\begin{array}{l}\text { Perception of } \\
\text { being better off } \\
\text { in } 1998-99 \\
\text { than in } 1996-97\end{array}$ & $207,050.4$ & 113 & \multirow{2}{*}{.705} & \multirow{2}{*}{.966} \\
\hline $\begin{array}{l}\text { Perception of } \\
\text { being worse off } \\
\text { in } 1998-99 \\
\text { than in } 1996-97\end{array}$ & $205,190.1$ & 454 & & \\
\hline $\begin{array}{l}\text { More than } 50 \% \\
\text { of household } \\
\text { income from } \mathrm{ECl}\end{array}$ & $267,789.9$ & 272 & \multirow{2}{*}{.000} & \multirow{2}{*}{.001} \\
\hline $\begin{array}{l}\text { Less than } 50 \% \\
\text { of household } \\
\text { income from } \mathrm{ECl}\end{array}$ & $160,117.1$ & 395 & & \\
\hline
\end{tabular}

\section{Adjustment through increased reliance on forest resources}

The quantitative and qualitative surveys both confirm that a large number of households adjusted to the adverse effects of the crisis partly through increasing their reliance on forest resources. (Note that "forest resources" are here defined broadly as timber and also non-timber forest resources.) The findings tend to confirm the second hypothesis related to wellbeing which states that there would be greater reliance on non-timber forest products as a result of the crisis.
The number of study households obtaining cash income from forest resources rose from 245 (23.3\% of all study households) in period 1 , to $263(25.0 \%)$ in period 2 , to $345(32.9 \%)$ in period 3 (Figure 12). Note, however, that there is considerable variability among the study provinces in the numbers of households receiving cash income from forest resources (Figure 13). Use of forest resources rose during the crisis in all study provinces except East Kalimantan. (There were reports of considerable damage to forest resources in East Kalimantan because of the effects of the drought and fires in period 2.) In relative

Figure 12. Number of study households receiving cash income from forest resources, comparison of periods 1,2 and 3 .

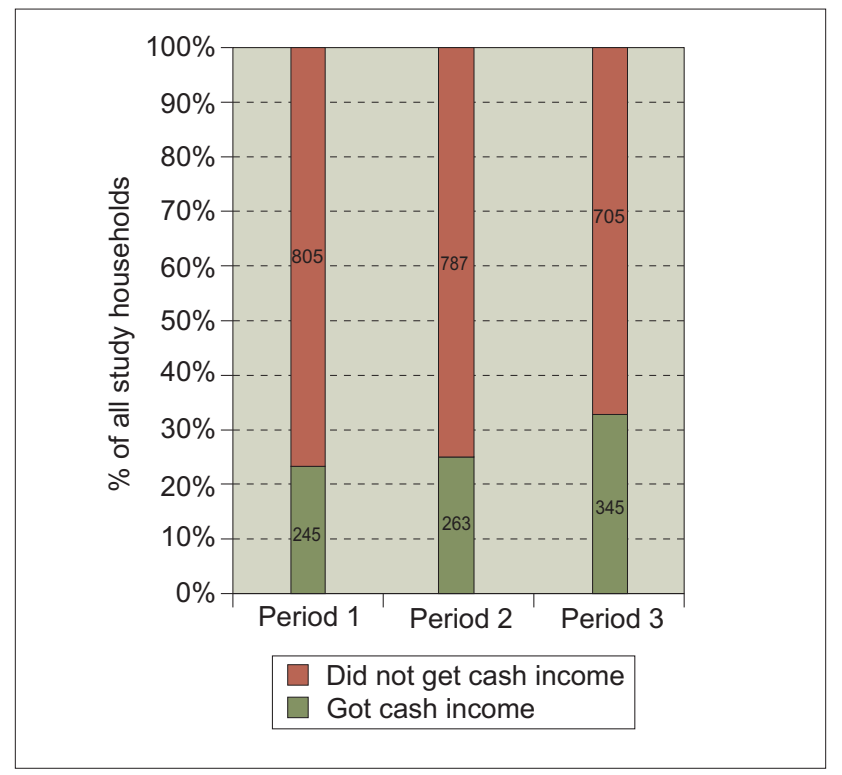

Figure 13. Number of households receiving cash income from forest resources, by study province and by study period.

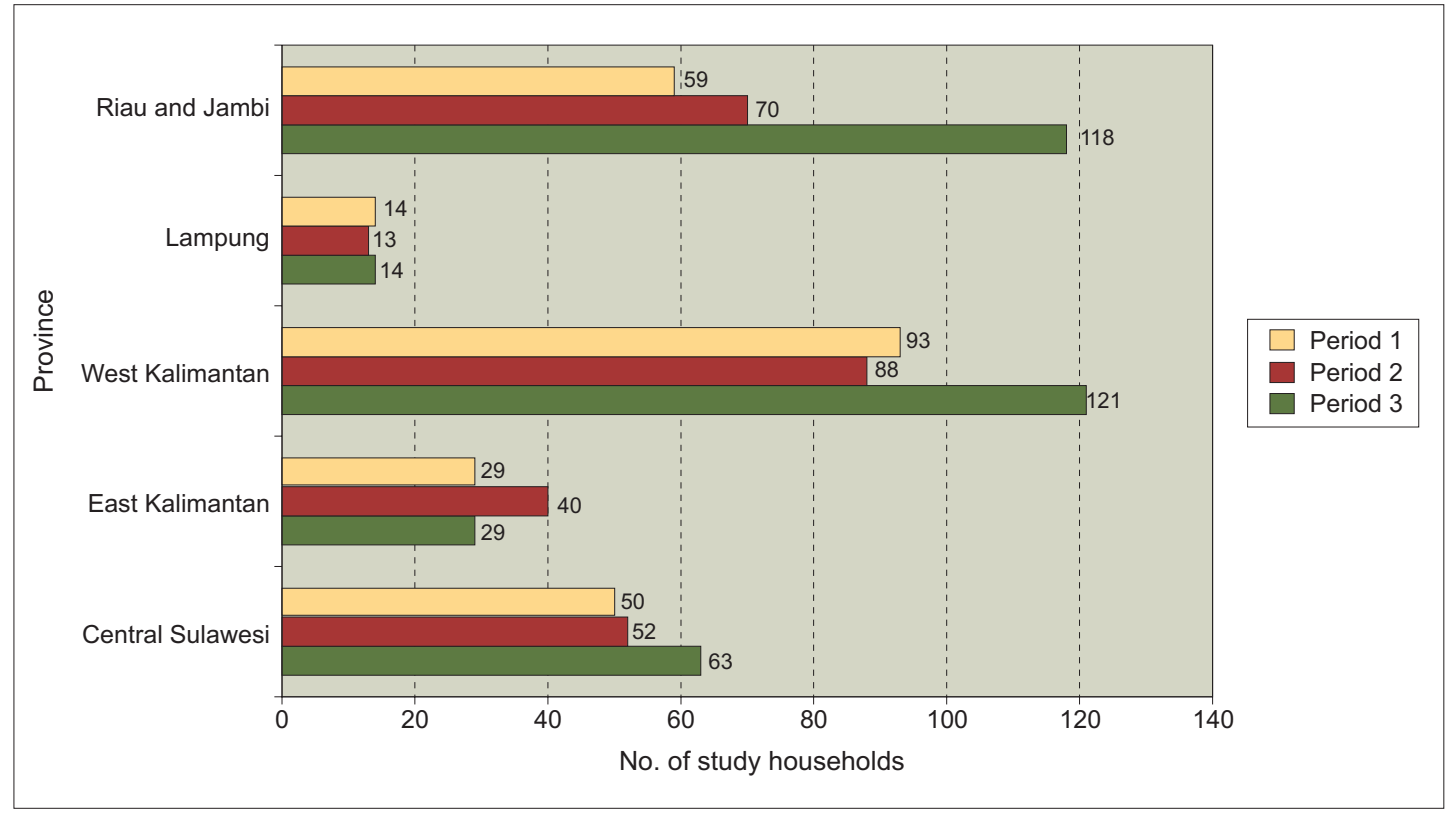


terms, the use of forest resources increased most strongly in Riau/Jambi, followed by West Kalimantan, Central Sulawesi and Lampung. It is noteworthy that this is more or less parallel to the order of the wellbeing outcomes for the study provinces (Figure 8). The study households in Riau/Jambi had the most difficult crisis experience, followed by Central Sulawesi, West Kalimantan, Lampung and then East Kalimantan.

Timber and rattan were by far the most important cashearning forest resources in terms of the number of study households making use of these resources, and in terms of growth in use over the period of the crisis (Figure 14). It is clear from the qualitative research that the decreased policing of forest access by the government played an important role in allowing increased exploitation of timber resources by small farmers. It would therefore be unwise to conclude that hardship is the only relevant factor explaining increased use of forest resources.

Figure 14. Number of households receiving cash income from forest resources, by resource type and by study period.

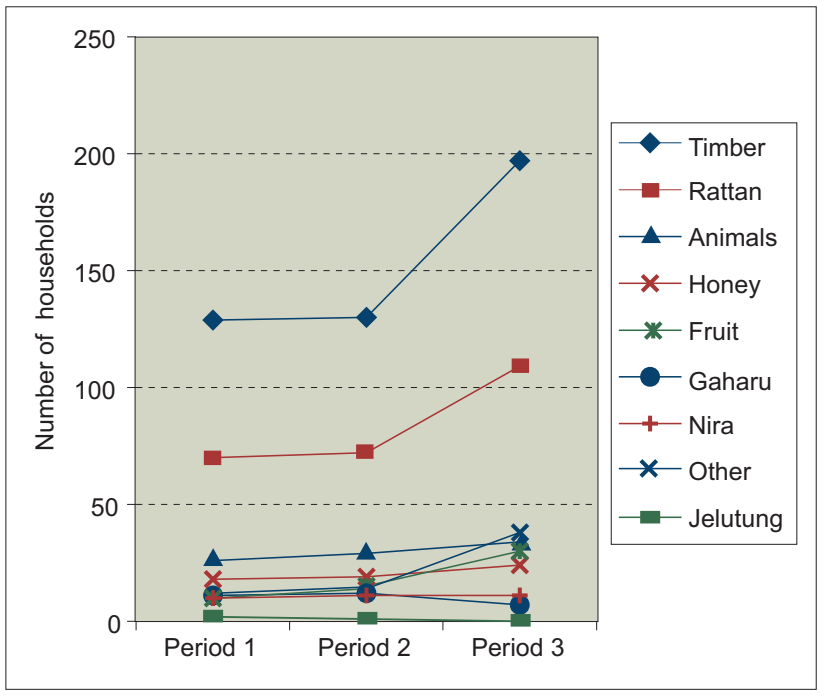

It is important to point out that the volume of forest resources used by the study households increased for some households and decreased for others. Questions on the reasons for increase and decrease were posed to those 433 respondents (38.4\% of total) who obtained cash income from forest products in both period 1 and period 3. Two hundred and thirty respondent households $(21.9 \%$ of the total) extracted timber from the forest in both periods 1 and 3. Exploitation of this resource increased from period 1 to period 3 for $137(59.6 \%)$ of the households, stayed the same for $18(7.8 \%)$ of the households, and decreased for 75 (32.6\%) of the households. Among the reasons for increased exploitation were: the higher price of timber $(69 \%$ of these respondents); larger number of buyers (41\%), locating of new supply areas (17\%), road improvement (12\%), and a larger family labour force (11\%). Among the reasons for decreased exploitation were: declining supply (56.4\%); increasing distance to supplies (53.8\%); declining household labour force (19.2\%); and increased competition (14.1\%).

One hundred thirty-seven respondent households (13.0\% of total) harvested rattan from the forest in periods 1 and 3. Exploitation of this resource increased from period 1 to period 3 for $89(65.0 \%)$ of these households, stayed the same for eight $(5.8 \%)$ of these households, and decreased for 40 (29.2\%). Among the reasons for increased exploitation were: higher price (49.4\%); increased number of buyers (39.3\%); and finding of new supplies (13.5\%). Among the reasons for decreased exploitation were: declining supply (70\%); greater distance to supply $(67.5 \%)$; and greater competition $(17.5 \%)$.

\section{Adjustment through migration}

The survey on migration revealed that there were very few heads of household ( 81 of the total 2,820 in the census or $2.9 \%$ ) that migrated to the study villages after the onset of the economic crisis. Of these 81 the great majority moved to the study villages in Central Sulawesi (34 households) or in Lampung (33 households). Only 31 $(38.3 \%)$ of the 81 households migrated because of reduced or lost sources of income at the point of origin. Fifty-six households (69.1\%) of the 81 moved to the study villages because the economic crisis created an incomeearning opportunity for them in those locations.

\section{Changes in household expenditure during the crisis}

One of the aims of the research was to understand why, in spite of the increased price of various export commodities (Figure 1), and the fact that the great majority of households have at least some ECI (Figure 6 ), and the greatly increased nominal income of households (Table 2), almost two-thirds of study households perceive themselves as worse off (Figure 7). The obvious reason so many households claim to be worse off is because the nominal cost of living increased faster than the nominal income, a finding well supported by data in the qualitative survey. To avoid a dramatic cutback in real consumption, many farmers have increased nominal expenditures more than nominal income. The effect has been a decline in savings and/or assets.

The quantitative data cannot document this clearly because questions were not posed about changes in overall household expenditures in the three study periods. 
The faster overall growth of expenditure over income is, however, demonstrated indirectly in two ways. First, the proportion of households declaring that nominal expenditure was greater in period 3 than in period 1 $(93.7 \%)$ is higher than the proportion of households declaring that nominal income was greater in period 3 than in period $1(80.2 \%)$. This is true not only at the aggregate level but in all study provinces as well. A second indirect indication is that average household expenditure for agricultural inputs increased through the three study periods, though average nominal household income increased dramatically from period 1 to period 2 , and then declined slightly in period 3 (Figure 15). Note however that, on average, agricultural input expenditures are a small fraction of overall expenditure and income. ${ }^{12}$

Figure 15 Comparison of gross average household income and average household expenditure for agricultural inputs, pre-crisis and crisis periods.

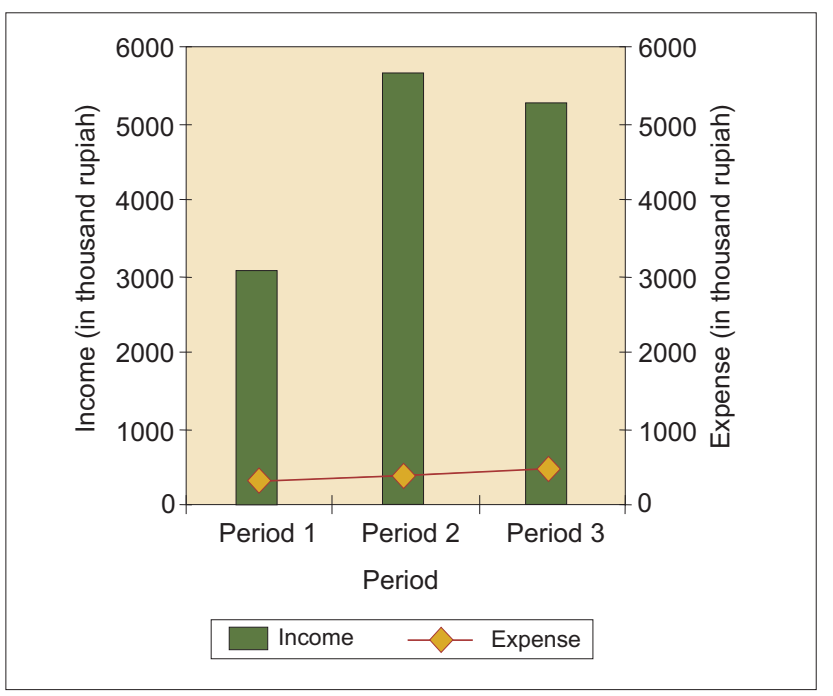

Note: This analysis includes all study households that used agricultural inputs, whether purchased or non-purchased.
The fact that household expenditure for agricultural inputs is, on average, a small fraction of household income should not disguise the fact that there are wide variations by province and by crop type. These variations can strongly affect household wellbeing in certain cases. Figure 16 shows data on the average per household cost of agricultural inputs disaggregated by study province and by study time period. Note that East Kalimantan has by far the highest costs and Riau/ Jambi and West Kalimantan the lowest. Figure 17 helps explain the wide divergence among study provinces in agricultural input costs. Observe that the input costs for pepper and oil palm are the two highest, and these two crops are strongly represented in East Kalimantan (see Figure 5). Conversely rubber has by far the lowest input costs among all major commodities represented in the study (Figure 17). This explains the low average agricultural input costs in Riau/Jambi and West Kalimantan, where rubber is by far the dominant crop.

\section{Desire for diversification}

One of the lessons that came out most strongly in the qualitative interviews was that farmers felt vulnerable when experiencing price volatility. In some interviews respondents said that they had introduced or were planning to introduce new crops in order to reduce the possibility of falling victim to future price declines. One crop that was mentioned often was oil palm. Respondents noted that diversification to new crops was inhibited by their lack of knowledge, land or capital.

Figure 16. Average household expenditure for agricultural inputs in 1996-97, 199798 and 1998-99.

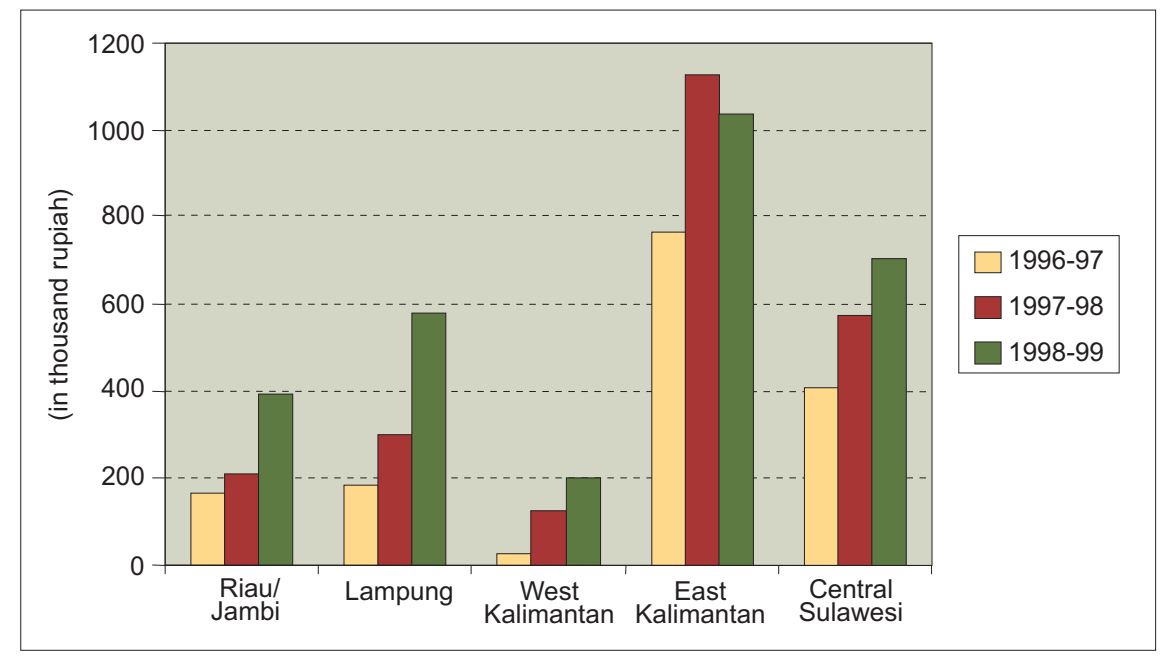


Figure 17. Average household expenditure for agricultural inputs by main income-producing crop, 1996-97, 1997-98 and 1998-99.

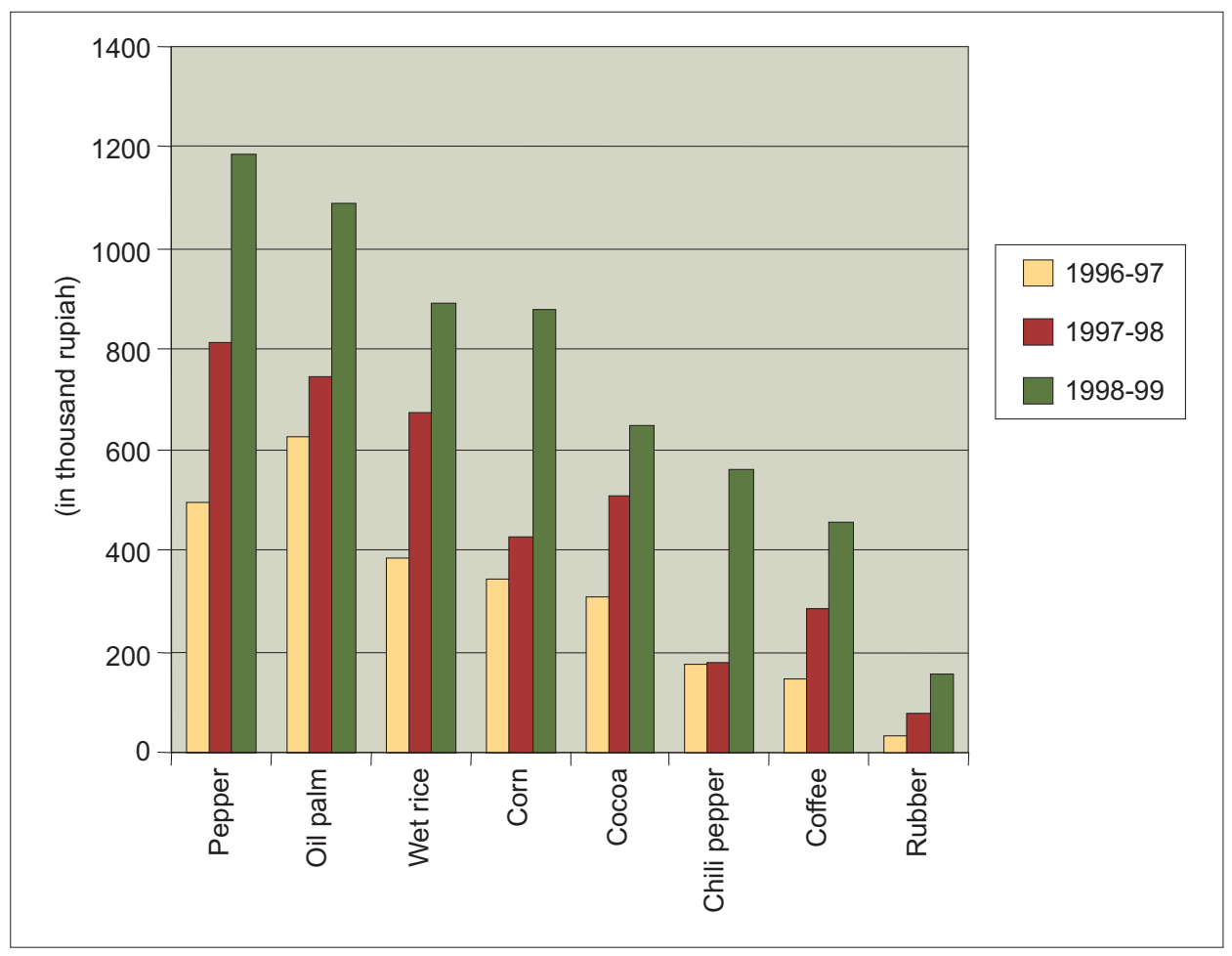

\subsection{Effects on natural forest cover}

\section{General findings on forest cover}

All respondents were asked whether they had cleared new land in the three years prior to the interview, that is between mid-1996 and mid-1999. Seven hundred and fourteen respondents ( $68 \%$ of the total) said they had cleared new land over this period. These respondents were asked to state the area of the parcel cleared and the purpose of the parcel according to three possible choices: (1) swidden cultivation only; (2) both swidden cultivation and sedentary agriculture; and (3) sedentary agriculture only. ${ }^{13}$

The results are shown in Figure 18 and display two important results. First, the number of clearings increased gradually from period 1 to period 2 , and then increased dramatically between period 2 and period 3 . (Note that the number of clearings exceeds the number of households because some households cleared more than one parcel of land in a given period.) Second, a notable change in the purposes of the clearings takes place over the three periods. The number of clearings for "swidden cultivation only" declined gradually across the periods. The number of clearings for both "swidden cultivation and sedentary agriculture" and for "sedentary agriculture only" increased moderately from period 1 to period 2 , and then increases dramatically from period 2 to period 3 .
Figure 18. Clearings of land for agriculture in 1996-1999 according to intended purpose.

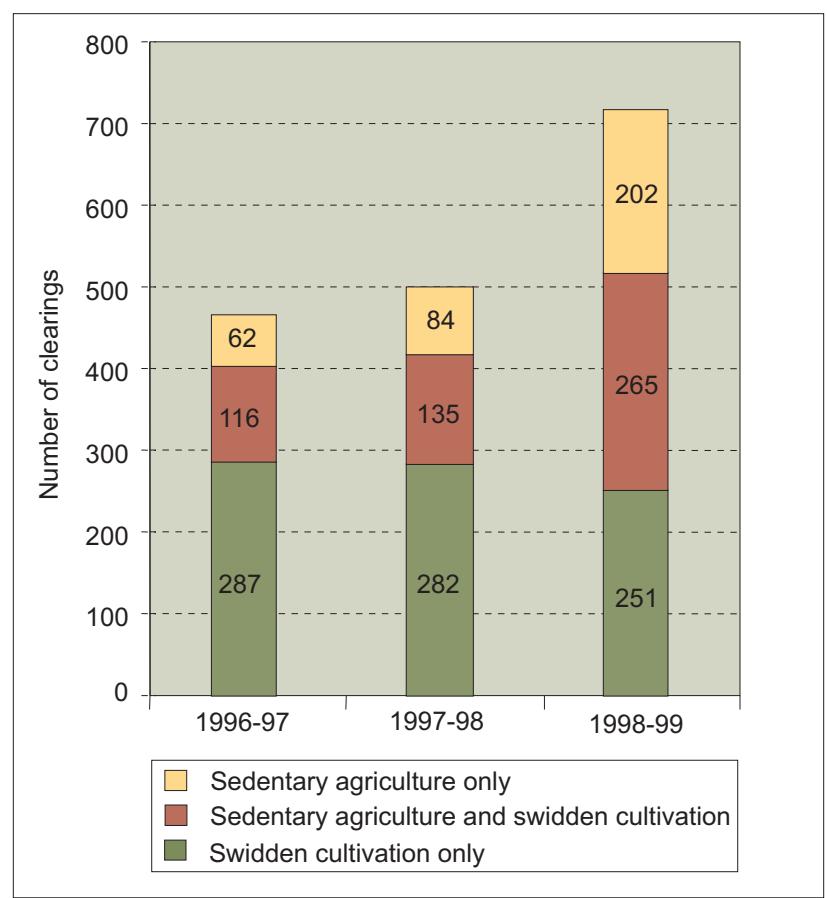

Table 9 shows the number and proportion of households clearing land during the crisis (that is to say, during periods 2 and 3 ), disaggregated by study province. There is remarkable variation in the frequency of land clearing among the provinces. The great majority (92.9\%) of study 
households in West Kalimantan cleared land during the crisis whereas less than a third $(30.5 \%)$ of study households in Lampung cleared land during the crisis. The high rate of land clearing in West Kalimantan as well as in Riau/Jambi (with a rate of $76.2 \%$ ) is partly explained by the prevalence of rubber and the interest in clearing more land for rubber. (This issue is discussed in greater detail later.) The low rate of land clearing in Lampung is explained partly by the relative unavailability of forest land to clear in that province.

Table 9. Proportion of study households clearing land during the crisis (periods 2 and 3 ) by province.

\begin{tabular}{|c|c|c|c|}
\hline \multirow[t]{2}{*}{ Province } & \multicolumn{2}{|c|}{$\begin{array}{c}\text { Did the household clear } \\
\quad \text { land during the crisis } \\
\text { (i.e. in 1997-98 and 1998-99)? }\end{array}$} & \multirow[t]{2}{*}{ Total } \\
\hline & Yes & No & \\
\hline Riau/Jambi & $\begin{array}{r}160 \\
(76.2 \%)\end{array}$ & $\begin{array}{r}50 \\
(23.8 \%)\end{array}$ & $\begin{array}{r}210 \\
(100 \%)\end{array}$ \\
\hline Lampung & $\begin{array}{r}64 \\
(30.5 \%)\end{array}$ & $\begin{array}{r}146 \\
(69.5 \%)\end{array}$ & $\begin{array}{r}210 \\
(100 \%)\end{array}$ \\
\hline West Kalimantan & $\begin{array}{r}195 \\
(92.9 \%)\end{array}$ & $\begin{array}{r}15 \\
(7.1 \%)\end{array}$ & $\begin{array}{r}210 \\
(100 \%)\end{array}$ \\
\hline East Kalimantan & $\begin{array}{r}157 \\
(74.8 \%)\end{array}$ & $\begin{array}{r}53 \\
(25.2 \%)\end{array}$ & $\begin{array}{r}210 \\
(100 \%)\end{array}$ \\
\hline Central Sulawesi & $\begin{array}{r}95 \\
(45.2 \%)\end{array}$ & $\begin{array}{r}115 \\
(54.8 \%)\end{array}$ & $\begin{array}{r}210 \\
(100 \%)\end{array}$ \\
\hline Total & $\begin{array}{r}671 \\
(63.9 \%)\end{array}$ & $\begin{array}{r}379 \\
(36.1 \%)\end{array}$ & $\begin{array}{r}1,050 \\
(100 \%)\end{array}$ \\
\hline
\end{tabular}

The respondents who cleared land were asked to state the area of the parcel cleared (as noted above) and also to specify the type of land cleared, according to the following categories:

- primary forest

- secondary forest aged 30 or more years

- secondary forest aged 10-30 years

- secondary forest aged 6-10 years

- secondary forest aged 1-5 years

- grassland or bushland

- burned forest land

- plantations or gardens

- other

The results, showing the total area of land cleared by the study households, and disaggregated by type of land cleared and by study province, are displayed in Figure 19. It is striking that the area of land cleared during the crisis in West Kalimantan is almost twice as large as that cleared in Riau/Jambi and East Kalimantan, four times as large as that cleared in Central Sulawesi, and eight times as large as that cleared in Lampung. Data not contained in this figure show that the average area of land cleared per household in West Kalimantan during the crisis (2.36 ha) is also large compared to the other provinces: 1.60 ha in East Kalimantan; 1.48 ha in Riau/Jambi; 1.12 ha in Central Sulawesi; and 0.95 ha in Lampung. So the large provincial disparities in total area of land cleared are a reflection not only of the varying numbers and proportions of study households clearing land (Table 9) but also of wide divergences in the average area cleared per household.

Figure 19 also shows important provincial differences in the types of land cleared. The proportions of land cleared in the two oldest forest age classes (primary forest and secondary forest aged 30 or more years) range from the highest in Riau/Jambi (about half the total in that province) to the lowest in Lampung (no such forests cleared at all). The clearing of these forest types as a proportion of all land cleared in the other three provinces is low, in the range of $5-15 \%$. Note that the clearing of young secondary forests (aged 1-5 years and 6-10 years) accounts for most land cleared in West Kalimantan, Central Sulawesi and Lampung; less than half in East Kalimantan; and about a third in Riau/Jambi. Note also that the great majority of land cleared in all five study provinces is forested rather than unforested land.

\section{Forest clearing in relation to levels of ECI}

The hypotheses on the issue of forest clearing proposed that high ECI households would tend to clear more land during the crisis than before the crisis, and that low ECI households show a wide diversity of land clearing from high, to medium, to low. The general assumption here is that, on average, ECI households would clear more land during the crisis than low ECI households. Statistical tests where done to see if levels of ECI were related in any significant way to either the frequency of forest clearing, or to the average area cleared.

A chi-square analysis was done through crosstabulating the variable "cleared land during the crisis (periods 2 and 3 )" (yes or no) with the binary variable level of ECI income in period 3 (high or low). The results (Table 10) show that $284(64.3 \%)$ of 442 high ECI households and $341(62.6 \%)$ of 545 low ECI households cleared land during the crisis, and that differences between these two proportions is not statistically significant.

An independent means difference test was done to see if the average area of land cleared by high ECI and low ECI households was significantly different. Table 11 shows that the average area of land cleared by low ECI households is slightly larger than that cleared by high ECI households in periods 1, 3, and 2- 3, but lower in period 2 . The differences are not statistically significant. 
Figure 19. Total area of land cleared by study households during the crisis (mid-1997 to mid-1999), by province and by landcover type.

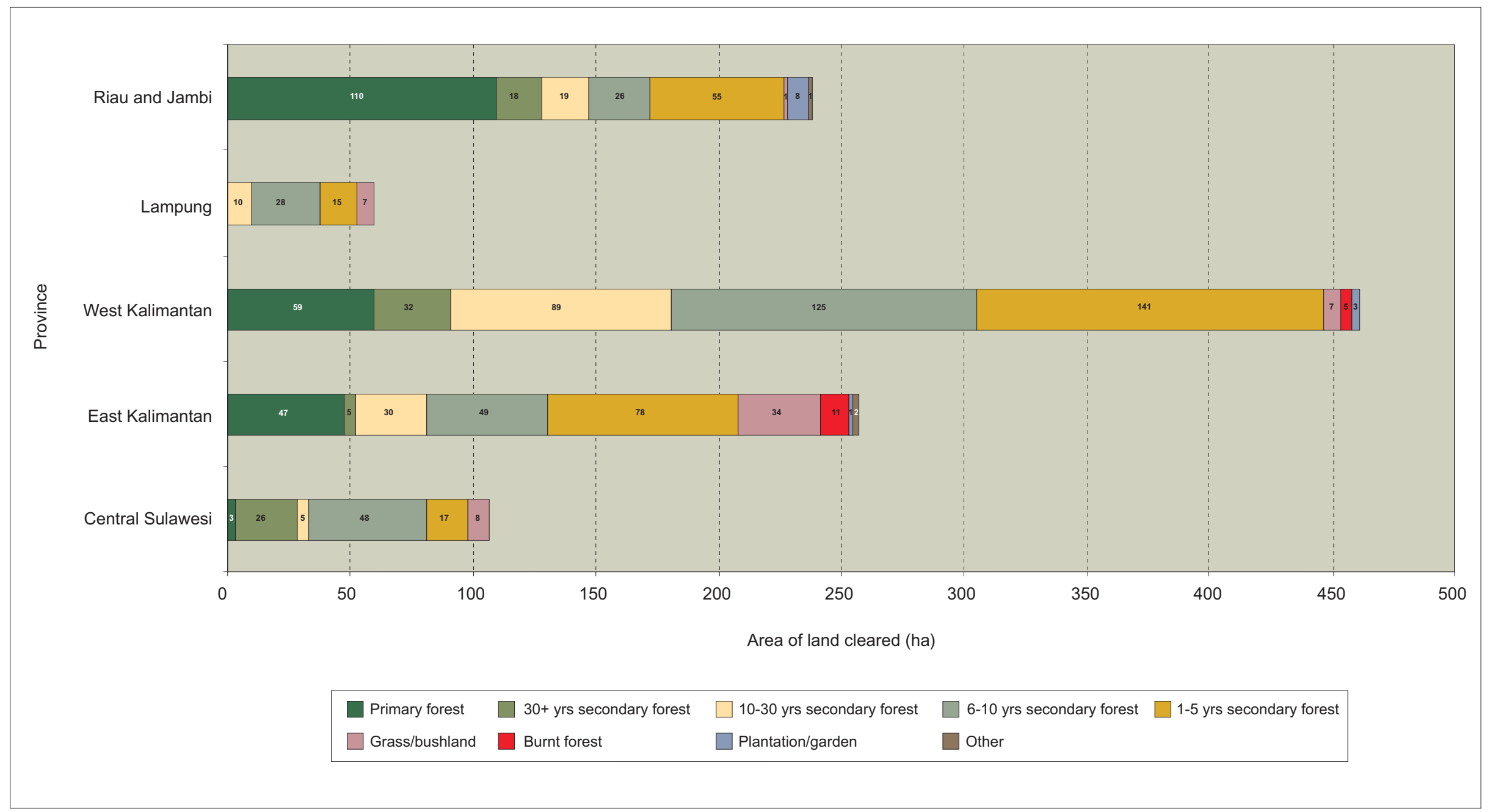


Table 10. Chi-square analysis of who clears land during the crisis (periods 2 and 3 ) by level of export commodity income (high or low).

\begin{tabular}{|c|c|c|c|c|}
\hline & & \multicolumn{2}{|c|}{$\begin{array}{l}\text { Did the household clear land } \\
\text { during the period of the crisis? } \\
\text { (Periods } 2 \text { and } 3 \text { ) }\end{array}$} & \multirow[t]{2}{*}{ Total } \\
\hline & & Yes & No & \\
\hline \multirow{2}{*}{$\begin{array}{l}\text { Level of export } \\
\text { commodity } \\
\text { income in } \\
\text { period } 3\end{array}$} & $\begin{array}{c}\text { High } \\
(\geq 50 \%)\end{array}$ & $\begin{array}{r}284 \\
(64.3 \%)\end{array}$ & $\begin{array}{r}158 \\
(35.7 \%)\end{array}$ & $\begin{array}{r}442 \\
(100 \%)\end{array}$ \\
\hline & $\begin{array}{c}\text { Low } \\
(<50 \%)\end{array}$ & $\begin{array}{r}341 \\
(62.6 \%)\end{array}$ & $\begin{array}{r}204 \\
(37.4 \%)\end{array}$ & $\begin{array}{r}545 \\
(100 \%)\end{array}$ \\
\hline \multicolumn{2}{|l|}{ Total } & $\begin{array}{r}625 \\
(63.3 \%)\end{array}$ & $\begin{array}{r}362 \\
(36.7 \%)\end{array}$ & $\begin{array}{r}987 \\
(100 \%)\end{array}$ \\
\hline
\end{tabular}

\begin{tabular}{|c|c|c|c|c|c|}
\hline \multicolumn{6}{|c|}{ Chi-Square Tests } \\
\hline & Value & df & $\begin{array}{l}\text { Asymp.Sig. } \\
\text { (2-sided) }\end{array}$ & $\begin{array}{l}\text { Exact.Sig. } \\
\text { (2-sided) }\end{array}$ & $\begin{array}{l}\text { Asymp.Sig. } \\
\text { (2-sided) }\end{array}$ \\
\hline $\begin{array}{l}\text { Pearson } \\
\text { Chi-Square }\end{array}$ & $.298^{\mathrm{b}}$ & 1 & .585 & & \\
\hline $\begin{array}{l}\text { Continuity } \\
\text { Correction }^{\mathrm{a}}\end{array}$ & .230 & 1 & .631 & & \\
\hline $\begin{array}{l}\text { Likelihood } \\
\text { Ratio }\end{array}$ & .298 & 1 & .585 & & \\
\hline $\begin{array}{l}\text { Fisher's } \\
\text { Exact Test }\end{array}$ & & & & .596 & .316 \\
\hline $\begin{array}{l}\text { Linear- } \\
\text { by-Linear } \\
\text { Association }\end{array}$ & .298 & 1 & .585 & & \\
\hline $\begin{array}{l}\mathrm{N} \text { of Valid } \\
\text { Cases }\end{array}$ & 987 & & & & \\
\hline
\end{tabular}

$a=$ Computed only for a $2 \times 2$.

$\mathrm{b}=0$ cells $(0 \%)$ have expected count less than 5 .

The minimum expected count is 162.11 .

\section{Changes in agricultural practices}

The changes in forest clearing practices are, as implied in Figure 18, strongly related to changes in agricultural practices during the crisis. Clearing of land specifically for non-export food crops (notably dry rice in swidden cultivation systems) declined in absolute and relative terms with the progression from periods 1 , to 2 , to 3 . Clearing of land for export tree crops of various kinds increased slowly between periods 1 and 2 , and then rapidly between periods 2 and 3 .

These progressions are evident as well in data on the change in relative area of land dedicated to particular crops during the three study periods. Figure 20 shows the relative change (larger, same, or smaller) of particular crops between periods 3 and 1, by number of households, and differentiated between export crops (top of figure) and food crops (bottom of figure). Notice that for six of the eight export commodities (all but rattan and coconut), the number of households increasing their area is two or more times greater than the number of households decreasing their area of the particular crop. In the cases of rubber, cocoa, pepper and oil palm, the ratio of increase over decrease is three or more. Contrast this to the situation of food crops where only rice and banana show significant numbers of households increasing area compared to those decreasing area of crops.

Table 11. Independent means test of average area of land cleared, differentiated by high and no/low $\mathrm{ECl}$, pre-crisis and crisis.

\begin{tabular}{|c|c|c|c|c|c|}
\hline Time period & $\begin{array}{l}\mathrm{ECl} \text { income } \\
\text { as proportion } \\
\text { of total }\end{array}$ & $\begin{array}{l}\text { Number of } \\
\text { households }\end{array}$ & $\begin{array}{l}\text { Mean area of } \\
\text { land cleared } \\
\text { (ha) }\end{array}$ & $\begin{array}{l}\text { Significance } \\
\text { (equality of }^{\text {variances) }}\end{array}$ & $\begin{array}{l}\text { Significance } \\
\text { (2-tailed equality } \\
\text { of means) }\end{array}$ \\
\hline Period 1 & $\geq 50 \%$ & 166 & 1.09 & \multirow{2}{*}{.226} & \multirow{2}{*}{.819} \\
\hline$(1996-97)$ & $<50 \%$ & 221 & 1.11 & & \\
\hline Period 2 & $\geq 50 \%$ & 168 & 1.23 & \multirow{2}{*}{.945} & \multirow{2}{*}{.299} \\
\hline (1997-98) & $<50 \%$ & 231 & 1.14 & & \\
\hline Period 3 & $\geq 50 \%$ & 250 & 1.00 & \multirow{2}{*}{.206} & \multirow{2}{*}{.426} \\
\hline (1998-99) & $<50 \%$ & 298 & 1.06 & & \\
\hline Periods $2-3$ & $\geq 50 \%$ & 284 & 1.60 & \multirow[t]{2}{*}{.211} & \multirow[t]{2}{*}{.440} \\
\hline (1997-99) & $<50 \%$ & 340 & 1.70 & & \\
\hline
\end{tabular}

$\mathrm{a}=$ equal variances assumed.

In summary, these tests jointly demonstrate that there is no significant difference in the forest clearing practices of high and low ECI households, in terms of frequency of clearing or area cleared during the crisis. The four hypotheses based on an assumption of fundamental differences are therefore largely rejected, although there are parts of the hypotheses that may be true. (This will be discussed later.)
These tendencies are even more evident when observing intended land use changes over time. The respondents were asked to name the primary crop (in terms of value) to be produced over the lifetime of the parcel, on parcels of land cleared in periods 1, 2 and 3 (Table 12). Dry rice is the main intended crop on $61.6 \%$ of parcels of land cleared in period 1; this proportion decreases to $53.7 \%$ in period 2 , and then plummets to $34.4 \%$ in period 3 . 
Figure 20. Change in the area of export crops and of food crops, second year of crisis (199899) as compared to year before crisis (1996-97).

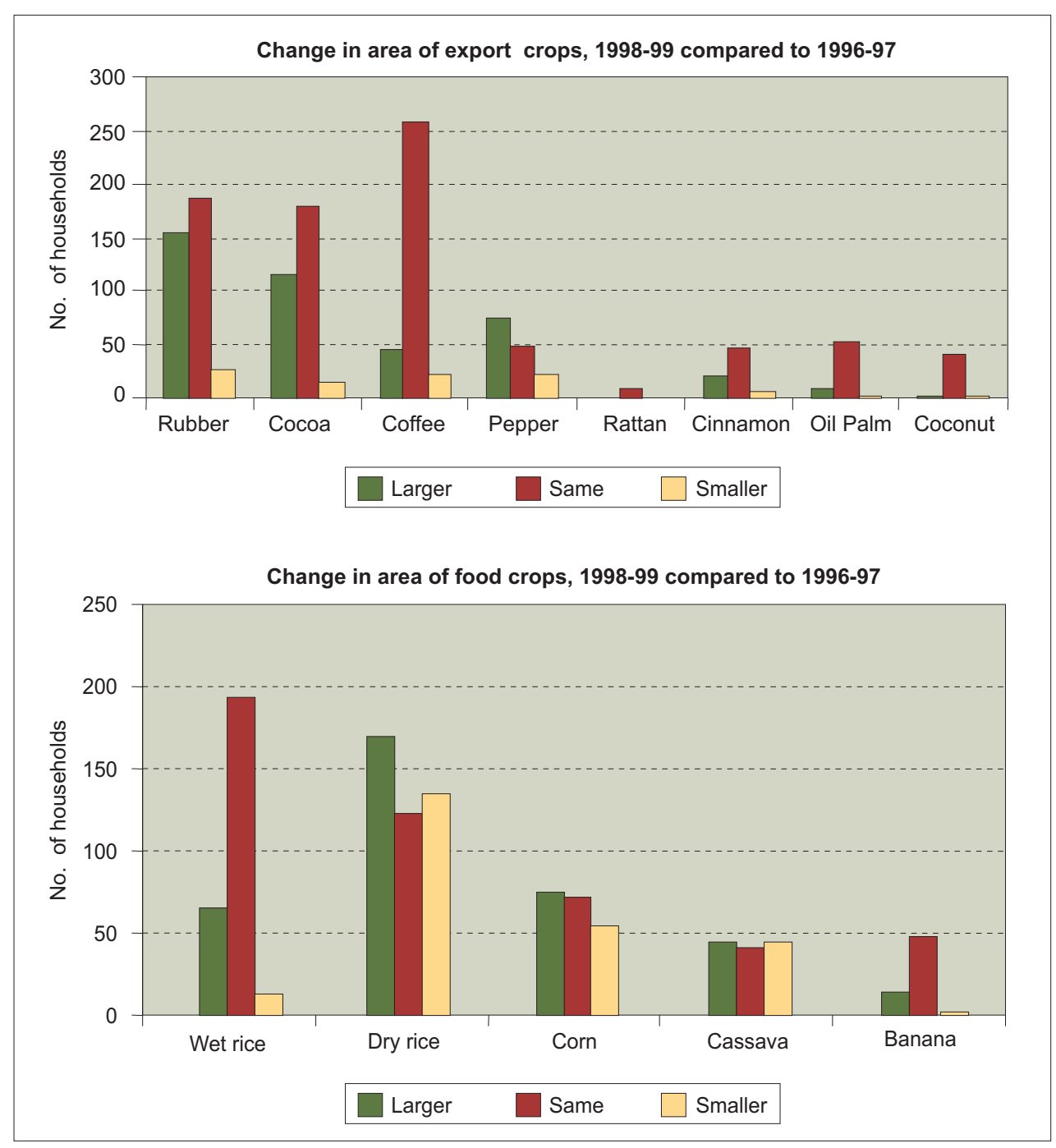

Table 12. Number of land clearings by primary crop type (in terms of value) over the lifetime of the parcel, in periods 1,2 and 3.

\begin{tabular}{|c|c|c|c|c|c|c|}
\hline \multirow[t]{2}{*}{ Crop type } & \multicolumn{2}{|c|}{$\begin{array}{l}\text { Period } 1 \\
(1996-97)\end{array}$} & \multicolumn{2}{|c|}{$\begin{array}{l}\text { Period 2 } \\
(1997-98)\end{array}$} & \multicolumn{2}{|c|}{$\begin{array}{l}\text { Period } 3 \\
(1998-99)\end{array}$} \\
\hline & $\mathrm{N}$ & $\%$ & $\mathrm{~N}$ & $\%$ & $\mathrm{~N}$ & $\%$ \\
\hline Dry rice & 284 & 61.6 & 266 & 53.7 & 243 & 34.4 \\
\hline Rubber & 83 & 18.0 & 99 & 20.0 & 193 & 27.3 \\
\hline Pepper & 10 & 2.2 & 20 & 4.0 & 64 & 9.1 \\
\hline Cocoa & 30 & 6.5 & 42 & 8.5 & 58 & 8.2 \\
\hline Coffee & 6 & 1.3 & 11 & 2.2 & 50 & 7.1 \\
\hline Wet rice & 6 & 1.3 & 14 & 2.8 & 47 & 6.6 \\
\hline Cinnamon & 21 & 4.6 & 15 & 3.0 & 26 & 3.7 \\
\hline $\begin{array}{l}\text { Mixed food } \\
\text { crops }\end{array}$ & 6 & 1.3 & 13 & 2.6 & 11 & 1.6 \\
\hline Other & 13 & 2.8 & 11 & 2.2 & 11 & 1.6 \\
\hline Corn & 2 & 0.4 & 4 & 0.8 & 4 & 0.6 \\
\hline Total & 461 & 100.0 & 495 & 100.0 & 707 & 100.0 \\
\hline
\end{tabular}

Note: This includes data for both the first and second parcels cleared.
The numbers of land clearings intended for export crops (rubber, pepper, cocoa, coffee, and cinnamon) jointly increase from $32.6 \%$ in period 1 , to $37.7 \%$ in period 2 , to $55.4 \%$ in period 3 .

\section{The rubber paradox}

The changing agricultural and land clearing practices described above can be, by and large, explained in terms of the commodity price shifts presented in Figure 1. It makes sense that as export crop prices tend to increase greatly in comparison to those of non-export food crops, production of export crops will tend to displace nonexport food crops. This is true even though there can be a substantial time delay (two to ten years) between the time of planting a tree crop and getting a marketable yield.

But rubber presents us with an apparent paradox. If the price of rubber has been relatively unchanged (Figure 1), why have the households increasing their rubber area 
during the crisis outnumbered those decreasing their rubber area by a factor of five (Figure 20), and why have the number of land clearings with rubber as the intended main crop more than doubled from 83 in period 1 to 193 in period 3 (Table 12)? In short, why is rubber growing in popularity at a time when its comparatively stagnant price suggests that it should be declining in popularity? This is a key question not only in terms of understanding wellbeing outcomes for study households, but also in terms of understanding land clearing practices, because a large amount of the forest cleared during the crisis is in West Kalimantan (Figure 19) and the dominant crop in that province by far is rubber (Figure 5). The apparent paradox applies in the same way in Riau/Jambi, where land clearing for rubber is also strongly evident.

An explanation for this apparent paradox can be found by examining the characteristics of rubber compared to alternative cash crops. Several attributes of rubber make it an appealing commodity during the crisis, in spite of its declining price. First, the costs in time and agricultural inputs (see Figure 17) for maintaining a rubber stand are low compared to other commodities. This is a key comparative consideration for farmers who are chronically time- and cash-constrained, and ever more so in the midst of an economic crisis. ${ }^{14}$ Second, unlike many other crops, rubber can be harvested throughout the year (with the exception of the rainy season), meaning that cash income can be accessed when the need arises rather than when the timing of the harvest dictates. (The harvest times of oil palm and coffee, for example, are not very flexible.) Third, rubber is relatively non-perishable, meaning it has easier marketing requirements than other crops, for example oil palm. Fourth, by mid-1998, at about the time when forests were cleared for new crops, the rubber price had increased somewhat in real terms (Figure 1), and nominal farm gate prices for rubber were two to three times higher than their pre-crisis level.

There are other characteristics of rubber that may explain expanded planting during the crisis. For farmers in the lowland peneplains of Sumatra and West Kalimantan, there are few or no alternatives to rubber, so it is not surprising that they increased their attention to a proven source of income. Lastly, latex production is limited more meaningfully by labour expenditure than by the number of tappable trees. In the short term, latex output can be increased by tapping existing trees more frequently and more vigorously. ${ }^{15}$

\section{Land clearing in relation to household wellbeing}

Information on land clearing was cross-classified with data on comparative wellbeing during the crisis to see if there were any significant tendencies with respect to respondents who perceived themselves as better off, the same, or worse off. Figure 21 shows the proportions of study households clearing land during the crisis in terms of the three wellbeing categories. Figure 22 shows the average area of land cleared per household in terms of the three categories.

Figure 21. Proportion of respondents clearing and not clearing land, by type of experience during the crisis.

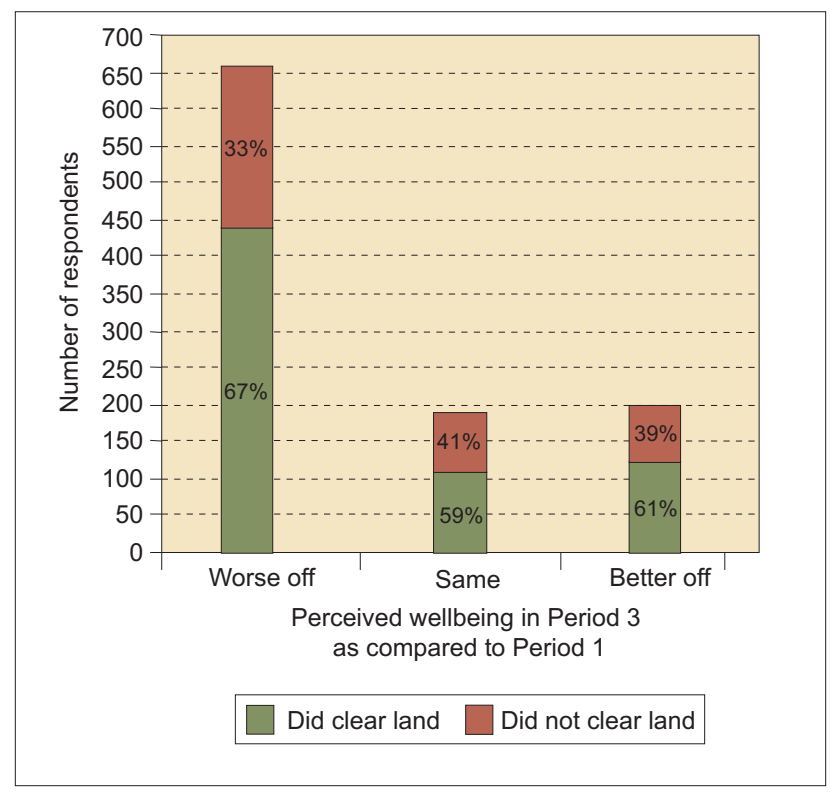

Figure 22. Average area of land cleared per household, by type of experience during the crisis.

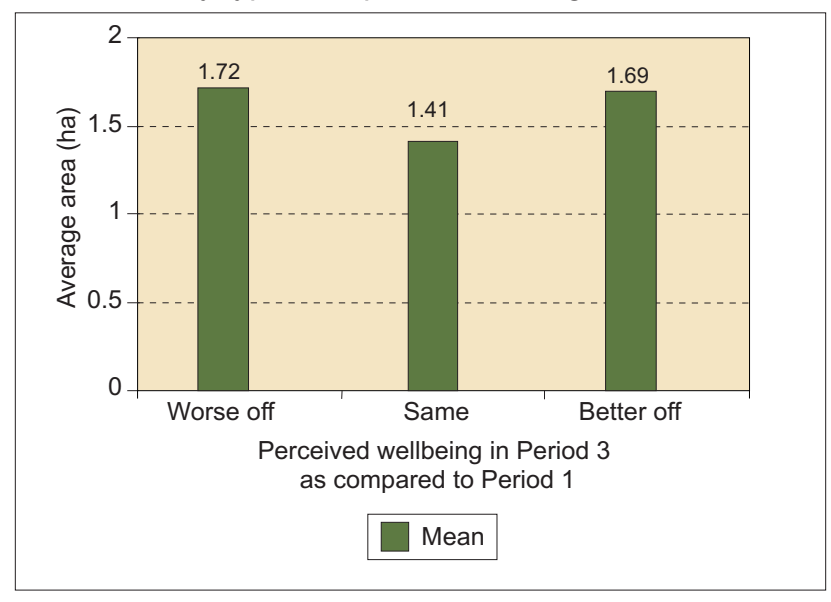


In both analyses it is readily apparent that there is a " $U$ shaped" phenomenon where "worse off" and "better off", at the extremes, tend to have higher values than "same". Specifically, the proportions of respondents clearing land who claim to be worse off $(67 \%)$ and better off $(61 \%)$ are higher than those who claim their wellbeing remains the same (59\%) (Figure 21). Likewise, the average areas of land cleared by households claiming to be worse off (1.72 ha) and better off (1.69 ha) are higher than those households claiming that their wellbeing remains the same (1.41 ha) (Figure 22).

Statistical tests were conducted to see if the "worse off/ same" and "better off/same" contrasts were significant. A chi-square test on the proportions of households clearing land showed that the difference between "worse off" $(67 \%)$ and "same" (59\%) is significant at the .10 level. The difference between "better off" and "same" is not statistically significant, but it must be borne in mind that those who claim to be better off often buy land as well. Recall that about one-sixth of those who claim to be better off buy land with their extra income (Figure 11). Stated differently, if the contrast between "better off" and "same" were framed in terms of land acquisition off, same, better off). One is left to wonder if there is something about the circumstances of the extremes of the crisis experience that generate a higher likelihood to clear land and to clear a larger area of land. Is it possible that those who perceive themselves as worse off are more likely to clear land, and to clear a larger area of land, because they are forced to by their circumstances? Conversely, is it possible that those who perceive themselves as better off are more likely to clear land, and to clear a larger area of land, because their increased income gives them the means to do so?

The data do not allow a full testing of this hypothesis, but additional analysis suggests that this is either not the explanation, or is not the full explanation. A crosstabulation of the average area of land cultivated by the study households and the three wellbeing categories shows that the "U-shaped" phenomenon predates the crisis; the phenomenon is therefore not (or not wholly) a product of the crisis (Table 13). Note that the average area of land cultivated is lower in all periods for those in the "same" category than for those in the "worse off" and "better off" categories. The differences are statistically significant at the .05 level for all periods.

Table 13. Average area of land cultivated per household by study periods and by perceived crisis experience.

\begin{tabular}{|c|c|c|c|c|c|c|}
\hline \multirow[t]{2}{*}{$\begin{array}{l}\text { Perceived crisis } \\
\text { experience }\end{array}$} & \multicolumn{2}{|r|}{$\begin{array}{l}\text { Period 1 } \\
(1996-97)\end{array}$} & \multicolumn{2}{|c|}{$\begin{array}{l}\text { Period 2 } \\
(1997-98)\end{array}$} & \multicolumn{2}{|c|}{$\begin{array}{l}\text { Period 3 } \\
(1998-99)\end{array}$} \\
\hline & $\mathrm{N}$ & $\begin{array}{l}\text { Average area } \\
\text { (ha) }\end{array}$ & $\mathrm{N}$ & $\begin{array}{c}\text { Average area } \\
\text { (ha) }\end{array}$ & $\mathrm{N}$ & $\begin{array}{c}\text { Average area } \\
\text { (ha) }\end{array}$ \\
\hline Worse off & 650 & 2.25 & 650 & 2.41 & 652 & 2.55 \\
\hline Same & 184 & 1.89 & 184 & 1.97 & 183 & 2.17 \\
\hline Better off & 198 & 2.58 & 198 & 2.68 & 198 & 2.81 \\
\hline Total & 1,032 & 2.25 & 1,032 & 2.38 & 1,033 & 2.53 \\
\hline
\end{tabular}

generally (i.e. both land clearing and purchasing), then the difference would probably be significant.

Independent means tests were done to test the average area cleared between "worse off/same" and "better off/ same". The difference between "worse off" and "same" is statistically significant at the .05 level in the joint periods 2 and 3 (period of the crisis) but not in any of the individual periods. The difference between "better off" and "same" is statistically significant at the .05 level in period 2 and at the .10 level in the joint periods 2 and 3 .

These statistical tests strengthen the impression that there are real differences occurring in land clearing practices with respect to the nature of the crisis experience (worse
Why are these differences evident even before the crisis began? At least part of the answer has to with happenstance related to differences in the average area of cultivation of particular crop types, and how these crop types are related to perceived household wellbeing during the crisis. Recall that the main income-producing crops of the study households are strongly differentiated in their relationship to wellbeing outcomes (Figure 9).

For purposes of testing this "happenstance" hypothesis, the eleven crop types in Figure 9 were put into three categories in accordance with their level of success in increasing wellbeing during the crisis. These categories of success are: (1) high for pepper, oil palm, coconut, and coffee; (2) intermediate for wet rice, cocoa, and 
miscellaneous food crops; and (3) low for corn, rubber, cinnamon, and chili pepper. Table 14 shows the average of cultivated land for study households cross-classified by these crop categories. The results support the happenstance hypothesis. The crops showing high success and low success have a high average area of cultivation, while the intermediate success crops have a relatively low area of cultivation. ${ }^{16}$
A hypothesis stating that dependence on non-timber forest products (NTFPs) would increase was verified. There was a broad tendency for farmers to compensate for lost agricultural income with income from the forest in a broadly sense (i.e. not just NTFPs but timber as well). Increased exploitation of timber was motivated not just by economic constraints but also by decreased presence of government forestry and security personnel in natural forest areas.

Table 14. Average area of land cultivated per household by study periods and by grouping of main crop type according to degree of success in facing the crisis (high, intermediate, low).

\begin{tabular}{|c|c|c|c|c|c|c|}
\hline \multirow[t]{2}{*}{$\begin{array}{l}\text { Main crop type by } \\
\text { success profile }\end{array}$} & \multicolumn{2}{|r|}{$\begin{array}{l}\text { Period } 1 \\
(1996-97)\end{array}$} & \multicolumn{2}{|c|}{$\begin{array}{l}\text { Period } 2 \\
(1997-98)\end{array}$} & \multicolumn{2}{|c|}{$\begin{array}{l}\text { Period } 3 \\
(1998-99)\end{array}$} \\
\hline & $\mathrm{N}$ & $\begin{array}{c}\text { Average area } \\
\text { (ha) }\end{array}$ & $\mathrm{N}$ & $\begin{array}{c}\text { Average area } \\
\text { (ha) }\end{array}$ & $\mathrm{N}$ & $\begin{array}{c}\text { Average area } \\
\text { (ha) }\end{array}$ \\
\hline High & 272 & 1.99 & 272 & 2.02 & 272 & 2.03 \\
\hline Intermediate & 227 & 1.68 & 227 & 1.75 & 229 & 1.96 \\
\hline Low & 340 & 3.23 & 340 & 3.48 & 340 & 3.72 \\
\hline Total & 839 & 2.41 & 839 & 2.54 & 841 & 2.69 \\
\hline
\end{tabular}

$\begin{array}{lll}\text { High } & =\text { Pepper, oil palm, coconut, coffee } \\ \text { Intermediate } & =\text { Wet rice, cocoa, miscellaneous food crops } \\ \text { Low } & =\text { Corn, rubber, cinnamon, chili pepper }\end{array}$

In summary, particular crops produced in the year before the crisis predisposed respondents to a particular wellbeing outcome. The tendency to clear land and the area cleared appeared to be positively related to the extremes of the wellbeing continuum (worse off and better off). In fact, however, the relationship is circumstantial, and more fundamentally related to the crop types which generated the different wellbeing outcomes.

\subsection{Summary of major findings}

Field research was conducted to understand the effects of Indonesia's economic crisis on: (1) the wellbeing of people living in or nearby natural forest areas in the outer islands; and (2) the forest cover consequences of crisisinduced changes in farming systems. Hypotheses were tested with respect to the wellbeing and forest cover consequences of the crisis.

A hypothesis stating that the consequences for household welfare would be more negative than expected was verified. In fact, the findings contradict the conventional wisdom that in general terms rural Indonesians would tend to escape the negative consequences of the crisis because of access to export income. Access to export income has not proven to be a buffer against the crisis because the cost of living and of agricultural production rose faster than gross income.
A hypothesis assuming that there are fundamental differences in the forest clearing practices of high- and low-ECI households was largely falsified. There are no significant differences between these two household types in terms of frequency of land clearing or of area cleared.

This last finding, however, does not mean the high- and low-ECI distinction was irrelevant. On the contrary, it was very relevant - both in terms of wellbeing and forest cover outcomes - but the relevance manifested itself in ways not anticipated in the formulation of the hypotheses. Among these ECI-related findings are the following:

- Gross household income was higher for low-ECI households than for high-ECI households in the year before the crisis, and then higher for highECI households than for low-ECI households during the crisis (Table 2).

- High-ECI households tended to have a better perceived wellbeing outcome during the crisis than low-ECI households (Table 3).

- There is a strong divergence in perceived wellbeing during the crisis (worse, same, better) according to the main cash crop produced by the household (Figure 9).

- High-ECI households got significantly more government aid during the crisis, but it is not clear what this means (Table 7). 
- Clearing of land increased dramatically in the second year of the crisis (Figure 18), and this was mainly associated with the aim of establishing export tree crops, either because of the their attractive price (e.g. pepper and cocoa), or for reasons related to long-term income security (e.g. rubber).

- During the crisis export tree crops expanded faster than food crops in terms of numbers of households expanding production (Figure 20) and in terms of the planned ultimate use of newly cleared land (Table 12).

Other key findings are not directly related to the issue of export commodity income:

- In the qualitative interviews many respondents said that their vulnerability had to do with being overly dependent on few crop types. Their income options were thus restricted at a time of dramatic price change.

- For households that experienced negative effects of both the drought/fires and the economic crisis, the effects of the former were judged to be worse than the latter in two provinces (Lampung and East Kalimantan) (Table 5).

- There is very high variability among the study provinces in the frequency of clearing land (Table 9 ), in the average amount of land cleared per household, and in the total land area cleared during the crisis (Figure 19).

- Those at the extremes of wellbeing in the crisis experience (perception of being worse off and better off) have a higher likelihood of clearing land (Figure 21) and of clearing a larger area of land (Figure 22) than those perceiving that their wellbeing remained the same. This outcome seems to have less to do with inherent characteristics of the crisis experience than it does with prior production of particular crops that led to divergent wellbeing outcomes (Tables 13 and 14).

\subsection{Unresolved questions}

Six research issues remain unresolved:

(1) What explains the widely divergent perceived wellbeing outcomes among study provinces? Specifically, why did East Kalimantan and Lampung appear to do relatively well, in the sense of being the only two study provinces where more than half the households claimed to have avoided a "worse off" outcome (Figure 8)? Why did households in these two provinces fare relatively well in spite of the fact that they were those most badly afflicted by the drought and fires, among the study provinces? The answer is not clear, but there is reason to suppose that the positive outcomes are linked to the dominance of non-rubber export crops in the mix of principal crops produced (Figure 5). (Riau/Jambi and West Kalimantan fared poorly, and rubber is the dominant crop in those provinces.) Another distinctive feature of East Kalimantan and Lampung is the diversity of export crops produced in comparison to the other study provinces (Figure 5 ).

(2) Is the increased attention of small farmers during the crisis to export tree crops and away from food crops a temporary or lasting phenomenon? The research data do not provide an answer to this question. It is important, however, to note two things. First, as mentioned earlier, a gradual trend away from swidden cultivation and toward sedentary tree crop cultivation predates the economic crisis (van Noordwijk 1995; Tomich et al. 1998). It remains to be seen whether, and if so, to what extent the crisis represents a significant modification of this pre-existing trend. Second, it is not just the crisis and commodity price changes that have caused increased attention to tree crops on small farms. Several respondents in the qualitative interviews remarked that increasing land pressures from population growth and in-migration, and consequent land scarcity, were motivating farmers to plant tree crops as property markers. It is also likely that decreased government control on entry to protected forests has motivated establishment of tree crops in these newly opened areas.

(3) What are the forest cover implications of a shift from tree crops to food crops, and from swidden cultivation to sedentary agriculture? In principle, one can assume that the implications would be positive for two reasons. First, on average, less land area is necessary in sedentary agriculture to achieve a given level of agricultural value than in swidden cultivation because it requires no clearing for fallow. Second, some tree crops tend to be grown in the shade of trees in agroforestry systems, potentially implying less extensive clearing of forests for a given level of agricultural value. It is not possible, however, to deduce this positive outcome on the basis of the research data because, as can be seen in Figure 18, the clearing of land for sedentary tree crops is largely additional rather than substituting for food crops and swidden cultivation.

(4) What are the forest-cover implications of crisisinduced human migration? Our results suggest that the implications are small, inasmuch as only $3 \%$ of study households had migrated to the villages since 
the onset of the crisis. But one has to wonder if this low rate of migration may be the outcome of deliberate selection of medium-sized study villages (see Appendix 3, "Strengths and weaknesses of the sample frame"). It is not clear if migrants to the outer islands tend to go disproportionately to small-, medium-, or large-sized villages. If for some reason they favour small- or large-sized villages, then the study may have under-represented the migrant population. Further research may be necessary to fully understand the forest-cover consequences of crisis-induced migration.

(5) What are the forest-cover implications of urban financiers who pay farmers to clear forest land for investment in agriculture? We found that urban financiers did invest in land clearing for investment in cocoa in Central Sulawesi, but we did not systematically investigate the scope of the practice there or in other provinces, nor the degree to which it was sensitive to price movements. It would be useful to better understand how investment capital exterior to the village economy may have facilitated additional forest clearing.

(6) To what extent was increased forest clearing during the period of the crisis a response to economic change, and to what extent was it a response to political change? The quantitative household survey data provide conclusive evidence of a causal link between price changes and forest clearing decisions. The qualitative data provide strong evidence that political change and, specifically, decreased policing of forest boundaries in the aftermath of the fall of Suharto, played a strong role in encouraging colonisation of protection forest areas. It remains to be determined how these two factors compare in their influences on forest-cover change, and how they interact.

\section{Conclusions and recommendations}

These research findings add to a growing body of recent literature showing that macroeconomic change can lead to unexpected and in some cases undesirable consequences for people living in forested areas and for the protection and management of remaining natural forests. These changes may be planned and intentional in the form of structural adjustment programs
(Kaimowitz et al. 1998) or currency devaluations (Eba'a Atyi 1998), or unplanned and spontaneous in the form of economic crises and currency and commodity price changes (Mertens et al. forthcoming; Ndoye and Kaimowitz forthcoming; Sunderlin et al. 1999).

The case of Cameroon is particularly instructive. Farmers devastated since 1986 by an economic crisis and collapse of export commodity prices have diversified away from cocoa and coffee monocultures towards mixed tree crop and food crop systems. The spontaneous diversification of crop types has probably been beneficial to farmers in the sense of helping protect them against the risks posed by monoculture dependence and possible future price shocks. The change in farming systems has, however, led to increased rates of deforestation, principally through land clearing for new food crop production. ${ }^{17}$ The situation of Indonesia is the opposite in the sense that the crisis has increased rather than decreased export commodity prices and made their production more attractive. But the fundamentals of the two crises are the same inasmuch as over-reliance on few crop types and reduced real purchasing power have had devastating consequences for farmer wellbeing, and abrupt changes in farming systems led to at least a temporary increase in the rate of forest clearing.

Two recommendations are made that might help avoid such outcomes in the future. First, it is recommended that an understanding of the possible adverse social and environmental consequences for forest dwellers and forests be incorporated in broad national and international policy planning processes. The word "broad" is emphasised because this action should not be limited to those policies that are concerned with the forest sector, but should include all possible relevant non-forest sector policies. It is becoming increasingly clear that non-forest policies have a greater role in determining the fate of forest dwellers and natural forests than do forest policies.

Second, it is recommended that programmes be designed to actively assist farmers in their efforts to diversify the crops they produce and their income sources. This will help mitigate the adverse effects on wellbeing of future commodity price shocks. To the extent that such a policy step succeeds in stabilising farm income and farming systems, it may also assist in diminishing that part of increased forest clearing that results from economic insecurity and volatility. 


\section{Acknowledgements}

We owe a large debt of gratitude to the survey respondents in the study villages, without whose patient and attentive cooperation this study could not have been carried out.

We give special thanks to the following individuals who participated in the conceptualisation of the research, spent many weeks away from home ably implementing the field survey, and wrote up extremely useful field reports: Iwan Kurniawan, M. Yusup Napiri, Wahyu Fathurrahman Riva, Soaduon Sitorus and Franky Zamzani. Ahmad Dermawan made an important contribution in compiling information on commodity price changes and assisting with data cleaning. Atie Puntodewo was painstaking in producing the map of our research sites. We are grateful to colleagues at CIFOR and the International Centre for Research in Agroforestry (South East Asia) who helped us in the selection of research sites. Several organisations were

\section{Endnotes}

${ }^{1}$ The threefold depreciation in the value of the rupiah against the U.S. dollar means that a given level of dollar income from the export of an agricultural commodity potentially produces a rupiah income that is three times higher than before.

${ }^{2}$ Although agriculture accounts for only about $20 \%$ of Indonesia's gross domestic product, it employs $45 \%$ of the country's labour force.

${ }^{3}$ Hill (1999:27-28, 45) says that the welfare of those in the agricultural sector has not been adversely affected directly, that "export growth rose, to the benefit of those deriving income from the sector" and that "many in the agricultural and informal sectors have experienced no great hardships, and possibly even an increase in incomes". Further, "the deterioration of living standards is serious but not catastrophic".

${ }^{4}$ Although small farmers are clearly an important cause of deforestation in Indonesia, their role in forest destruction may have been exaggerated. See Sunderlin (1997); Sunderlin and Resosudarmo (1996); Sunderlin and Resosudarmo (1999).

${ }^{5}$ Forest clearing by small farmers in the outer islands of Indonesia generally involves wholesale clearing of all vegetation. In some cases farmers may try to preserve a valuable tree in the clearing process (e.g. durian), but it usually suffers so much from fire used for clearing that it does not adequately recover. Personal communication with Meine van Noordwijk, 24 January 2000. extremely helpful in conducting the preparatory field visits, site selection, and fieldwork. These organisations are Yayasan Dian Tama of West Kalimantan, WWF Taman Nasional Bukit Tiga Puluh of Riau, Yayasan Pusaka Alam Nusantara of Central Sulawesi, and BIKAL of East Kalimantan.

We appreciate the efforts of the following individuals for insightful comments on a draft of this report: Jean Aden, Tim Brown, Anne Casson, Carol Pierce Colfer, David Kaimowitz, Stephen Mink, and Meine van Noordwijk. The authors alone are responsible for any errors that may remain.

This research project was made possible through grants from the World Bank and the MacArthur Foundation. The latter grant was part of CIFOR's collaboration with the Centre for Strategic and International Studies in Jakarta.

${ }^{6}$ According to van Noordwijk et al. (1995:11-12) Indonesia can be classified into four zones with respect to the transformation from shifting cultivation (called in this report "swidden cultivation") to permanent agriculture (called in this report "sedentary agriculture"): "(1) Java and Bali, where the transformation to permanent agriculture occurred before 1880; (2) North and West Sumatra and South Kalimantan, where the transition was nearly complete by the middle of the $20^{\text {th }}$ century; (3) most of Sumatra, where most of the transformation took place during the middle of the $20^{\text {th }}$ century; and (4) the rest of Kalimantan and Irian Jaya, which are still in the early stages of the transformation". This classification is based on data from Richards and Flint (1993:B8-B11).

7 For example see: "Shrimp ponds sweep away SE Sulawesi Mangrove Forests". The Jakarta Post. 8 June 1999, p.7; "Ratusan hektare hutan bakau berubah fungsi", Banjarmasin Post, 26 August 1998, (online); "Masa keemasan kakao di tengah krisis", Kompas, 17 January 1998, p.9; "Coffee business perks up in Central Aceh", Jakarta Post, 19 February 1998, p. 7; "Lampung pepper pickers profit from rupiah's demise", The Indonesian Observer, 4 August 1998, p.8.

${ }^{8}$ In examining this issue, it is important to distinguish biological and financial gestation. Rubber can be tapped only from year five or six onwards, but due to low investments it is profitable soon after. Oil palm, in contrast, starts to yield in year three, but because of high costs, investments are recovered until year nine (Personal communication, Meine van Noordwijk, 10 January 2000). 
${ }^{9}$ Given their relatively small area, Riau and Jambi were combined in the study.

${ }^{10}$ Research by Elmhirst et al. (1998), based on field work in North Lampung, shows how the effects of the crisis have been compounded by the extended drought of $1997-$ 98 in certain locations.

${ }^{11}$ The study had a four-scale rating of the impact of the crisis ranging from "very large", "large", "average", and "small". Lampung was given a rating of "large impact" in the categories "economic resilience", "food security and availability of goods", "unemployment and social security", and "health and family planning". Riau and Jambi were given a rating of "small impact" in the categories "economic resilience", "food security and availability of goods", "health and family planning", and "education".

${ }^{12}$ The analysis was limited to those households (536 in period 1; 526 in period 2; 570 in period 3) that used agricultural inputs - whether purchased or unpurchased. The fact that a substantial portion of these households (168 in period 1; 149 in period 2; and 140 in period 3) had no cash expenditure for their inputs means that the expenditure appears lower than it would be if the analysis were applied only to only those households that made some cash expenditure for their inputs.
${ }^{13}$ The phrasing of the question made it clear that we were interested in the use of the newly cleared land for the entire period and not just the use immediately after clearing. Note that "swidden cultivation" almost always implies planting of a dry rice crop, whereas "sedentary agriculture" implies tree crops such as rubber, cocoa, coffee, and others.

${ }^{14}$ This is true for traditional jungle rubber, but not for hybrid rubber varieties that were produced by few households in the survey sample.

${ }^{15}$ The insights in this paragraph were contributed by Meine van Noordwijk. Personal communication, 10 January 2000.

${ }^{16}$ Among the crops with high success, oil palm has the highest average area of cultivation (2.8 ha) and pepper follows with an average area of 2.5 ha. This raises the average for the category, which is numerically dominated by coffee (and whose average area is only 1.7 ha.). Among the crops with low success, rubber has by far the highest average ( $3.7 \mathrm{ha}$ ) and it is numerically dominant. The intermediate success category is numerically dominated by cocoa which has an average area of 1.9 ha.

${ }^{17}$ A currency devaluation of the CFA franc in January 1994 partly restored the attractiveness of producing export crops. 


\section{References}

Angelsen, A. and Resosudarmo, I.A.P. 1999. Krismon, farmers and forests: The effects of the economic crisis on farmers' livelihoods and forest use in the outer islands of Indonesia, Center for International Forestry Research (CIFOR). Bogor, Indonesia.

Biro Pusat Statistik (BPS). 1999. Laporan survei dampak krisis pada tingkat kecamatan di seluruh Indonesia 1998. BPS, Jakarta.

Booth, A. 1999. The impact of the crisis on poverty and equity. In: Arndt, H.W. and Hill, H. (eds.) Southeast Asia's economic crisis: Origins, lessons, and the way forward. Allen and Unwin, Australia. pp. 128-141.

Eba'a-Atyi, R. 1998. Cameroon's logging industry: Structure, economic importance, and effects of devaluation. Occasional Paper no. 14. Center for International Forestry Research (CIFOR). Bogor, Indonesia.

Economist Intelligence Unit (EIU). 1999. Country Report: Indonesia. $3^{\text {rd }}$ quarter 1999. The Economist Intelligence Unit, United Kingdom.

Elmhirst, B. , Hermalina, and Yuliyanti. 1998. 'Krismon' and 'Kemarau': A downward sustainability spiral in a North Lampung Translok Settlement. In: van Noordwijk and de Foresta, H. (eds.) Agroforestry in landscapes under pressure. Lampung research planning trip, 17-21 June 1998. ICRAF Southeast Asia.. Bogor, Indonesia.

Evans, K. 1998. Survey of recent developments. Bulletin of Indonesian Economic Studies 34(3):5-36.

Fraser, A.I. 1998. Social, economic and political aspects of forest clearance and land-use planning in Indonesia. In: Maloney, B.K. (ed.) Human activities and the tropical rainforest. Kluwer Academic Publishers, The Netherlands. pp. 133-150.

Hill, H. 1999. The Indonesian economy in crisis: Causes, consequences, and lessons. Institute of Southeast Asian Studies, Singapore.

Jellinek, L. and Rustanto, B. 1999. Survival strategies of the Javanese during the economic crisis. The World Bank, Jakarta.
Kaimowitz, D., Erwidodo, Ndoye, O., Pacheco, P and Sunderlin, W.D. 1998. "Considering the Impact of Structural Adjustment Policies on Forest in Bolivia, Cameroon and Indonesia". Unasylva 49(194):57-64.

Mertens, B., Sunderlin W.D., Ndoye, O., and Lambin, E.F. Forthcoming. Impact of Macroeconomic Change on Deforestation in South Cameroon: Integration of household and remotely-senses data. World Development.

Ndoye, O. and Kaimowitz, D. Forthcoming. Macroeconomics, markets, and the humid forests of Cameroon, 1967-1997. Journal of Modern African Studies.

Natural Resources Management Project (NRMP). 1999. Analysis of natural resource impacts of Indonesia's financial crisis. Briefing on a study commissioned by Deputy V of BAPPENAS, with updates through the third quarter of 1998. 28 January 1999.NRMP, Indonesia.

Poppele, J., Sumarto, S. and Pritchett, L. 1999. Social impacts of the Indonesian economic crisis: New data and policy implications. Social Monitoring and Early Response Unit (SMERU), Jakarta.

Richards, J.F. and Flint, E.P. 1993. Historic land use and carbon estimates for South and Southeast Asia 18801980. Environmental Sciences Division, Publication No. 4174. Oak Ridge, Carbon Dioxide Information Analysis Center, Oak Ridge National Laboratory, Tennessee.

Sunderlin, W. D. and Resosudarmo, I. A.P. 1996. Rates and causes of deforestation in Indonesia: Towards a resolution of the ambiguities. Occasional Paper No. 9. Center for International Forestry Research (CIFOR), Bogor, Indonesia.

Sunderlin, W.D. 1997. Shifting cultivation and deforestation in Indonesia: Steps toward overcoming confusion in the debate. Rural Development Forestry Network. Network Paper 21b. Overseas Development Institute, London.

Sunderlin, W. D. and Resosudarmo, I. A.P. 1999. The effect of population and migration on forest cover in Indonesia. Journal of Environment and Development 8(2):152-169. 
Sunderlin, W.D., Ndoye, O., Bikié, H., Laporte, N. and Pokam, J. 1999. Economic Crisis, Small-Scale Agriculture, and Forest Cover Change in Southern Cameroon. Unpublished manuscript.

Tomich, P. et al. 1998. Alternatives to slash and burn in Indonesia: Summary report and synthesis of phase II. International Centre for Research in Agroforestry, South East Asia. Bogor, Indonesia. van Noordwijk, M. et al. 1995. Alternatives to slash and burn in Indonesia: Summary report of phase I. International Centre for Research in Agroforestry, South East Asia. Bogor, Indonesia.

Warr, P.G. 1999. Indonesia's crisis and the agricultural sector. In: Simatupang, P., Pasaribu, S, Bahri, S and Stringer, R. (eds.) Indonesia's economic crisis: Effects on agriculture and policy responses. Centre for International Economic Studies, University of Adelaide. 


\section{Appendix 1.}

\section{Derivation of estimates of the number of swidden cultivators and forest villagers in the main outer islands of Indonesia}

\section{Derivation of the number of swidden cultivators}

Fraser (1998:140), drawing on Forest Department statistics, says there are 1.26 million households dependent on swidden cultivation (Fraser uses the term "shifting cultivation") in the five main islands of Indonesia, representing about $14 \%$ of the rural population of those islands. These five main outer islands are Sumatra, Kalimantan, Sulawesi, Irian Jaya, and the Moluccas (Fraser 1998:134).

According to field survey data for this research project, there are 4.79 household members in the average forest village household.

Multiplying the number of swidden cultivator households $(1,260,000)$ by the average number of household members (4.79) yields a total population in swidden cultivator households of $6,035,400$ or approximately six million people.

\section{Derivation of the number of forest villagers}

Forest villages are comprised of farmers producing only swidden crops, farmers producing only perennial crops, farmers producing both swidden and perennial crops, farm labourers, and others not actively involved in farming. According to field survey data for this project, swidden cultivators (defined as farmers producing only swidden crops or both swidden and perennial crops) are on average $29.1 \%$ of the total population of forest villages. Applying this figure to the estimated total number of swidden cultivators $(6,035,400 \div 0.291)$ yields $20,740,206$ or approximately 20 million forest villagers.

The ratio of $29.1 \%$ (swidden cultivators to total forest village population) was obtained in the following way. Of the 5,179 forest village households recorded in the preliminary household census for this research project, approximately 1,900 cleared forest land in the three-year period mid-1996 to mid-1999. (The actual figure is 1,756 , but we revised it upward to 1,900 because the census was done in March-April 1999 - before mid-1999 was reached.) It is assumed this figure encompasses all swidden cultivators, on the assumption that land is cleared by such households at least once every three years. We calculated from the 30-village household survey that $79.3 \%$ of all forest clearings in the period mid-1996 through mid-1999 were either for swidden alone, or for combined swidden and sedentary agriculture. Applying this ratio to the number of households that cleared forest land (1,900 x .793), we can estimate that the number of swidden cultivator households in the 40-village data set was 1,507 . To find the proportion of swidden cultivator households as a proportion of all forest village households we divide 1,507 by 5,179 , yielding $29.1 \%$.

It should be noted that this is a crude estimate of the numbers of swidden cultivators and forest villagers and that the actual figures may be lower or higher. Our calculation might over-estimate these figures from the standpoint that the estimate of 1.26 million swidden cultivation households dates back to the 1980s and we assume the numbers have been in decline. However, our calculation might also have under-estimated the true figures, given that the number of respondents in the 40village census saying they had cleared forest land may be low. (We know that some respondents, as yet unfamiliar with our research team at the time of the census, were hesitant to admit they had cleared forest land, especially in protection forest areas.)

It should also be noted that the number of swidden cultivators as a proportion of all forest villagers varies widely by village and by province. For example in our 40 -village census, only $30 \%$ of respondent households in the Lampung villages had ever cleared forest land, whereas at the other extreme, 95\% of respondent households in West Kalimantan had cleared forest land at some time. 


\section{Appendix 2.}

\section{Criteria for the selection of the study villages}

\section{The 30 study villages were chosen on the basis of the following six criteria:}

(1) There must be an adequate amount of forest cover in the study village area. Forests must have a $10 \%$ or greater crown cover within a 5 $\mathrm{km}$ radius of the village centre. The principal aim in fulfilling this criterion is to avoid those villages where the process of deforestation is so far advanced that agricultural expansion is barely noticeable with respect to forest cover change. Note that "forest" is defined as natural forest (whether primary or secondary regrowth), and does not include forest plantations.

(2) The practices of village farmers must have an appreciable impact on forest cover. By the best estimate of a local key informant, at least onethird of the inhabitants of the village must practise a form of agriculture that involves either regular or at least intermittent clearing of forest land, whether for swidden cultivation or for sedentary crops. (We were able to apply this criterion to all study provinces except Lampung, where lack of forest cover in several village areas meant less than a third of households cleared forest land.)
(3) Most of the village inhabitants produce agricultural crops and/or livestock for cash income. This is to ensure that most respondent households are part of the market economy, and that they have therefore experienced (positively or negatively) the effects of the drastic currency depreciation.

(4) There must be at least 40 households (the minimum sample size) and at most 200 households in each of the study villages. (In East Kalimantan, two neighbouring villages with fewer households than the minimum were joined together to form a "village" above the minimum size.)

(5) An attempt will be made to avoid those villages that have been severely affected by the drought and forest fires of 1997-98. In this way we aim to ensure that the pre- and post-crisis measurements of income and forest-clearing practices are a relatively faithful reflection of the economic crisis, and not of other phenomena.

(6) To the extent possible, the study villages within a given province will be dispersed so as to reflect socioeconomic and bioregional diversities. We recognise that in some provinces (e.g. Lampung and West Kalimantan) this criterion will be difficult to meet because of scarcity of remaining natural forest cover. 


\section{Appendix 3.}

\section{Strengths and weaknesses of the sample frame}

There are weaknesses and strengths in our sample frame that should be noted. First, as a matter of necessity, we selected the target villages systematically rather than randomly, as there was no database of forest villages to make use of. This approach "cuts both ways" in the sense of narrowing the type of village studied, and therefore increasing the potential representativeness of our sample, yet it does so on the basis of a largely unknown universe of village types, so there is not an ideally specified relationship between population and the sample. Second, in applying a flat sample size of 35 households per village, we are able to simplify village-level analysis, though at the cost of biasing the sample toward smaller villages. This is not a serious problem, however, as the range of sizes of study villages is fairly low (most are in the range of 85-115 households). Moreover, weighting of the sample by village size can overcome this problem. Third, in limiting the village size to between 40 and 200 households, we excluded smaller and larger villages. We do not view this to be a serious problem because very small villages (say, fewer than 20 households) tend to be fairly remote and may not have strong contact with markets, and large villages tend to be closer to urban areas and often have significantly less forest cover. In selecting medium-sized villages, we optimised the (potentially competing) criteria of maximum contact with the market and maximum remaining natural forest cover. 


\section{Appendix 4.}

\section{Stratification of the census data for selection of the household survey respondents}

The preliminary census collected information on 5,179 households in 40 villages. Selection of the 30 most appropriate target villages narrowed down the database to 2,820 households. In accordance with the following criteria, the database was narrowed further still to 2,668 households.

\section{The households chosen were limited to:}

(1) Heads of household who had lived continuously in the study village in the three-year period encompassed by the study (mid-1996 through mid1999). This specification aims to ensure that comparisons among the three study periods (mid1996 to mid-1997; mid-1997 to mid-1998; mid-1998 to mid-1999) for a given household is based on their activities in the study village alone. Stated differently, we wanted to avoid meaningless analyses where, for example, changes in income and changes in crops had more to do with a move from one village to another than with factors related to the crisis.
(2) Heads of household who were "farmers" in the sense of farming land over which they have control in land management decisions. We avoided inclusion of farm labourers, for whom changes in commodity prices would not imply changes in land management decisions.

From these 2,668 households, 1,050 households (35 in each of 30 villages) were randomly chosen to be respondents for the household survey.

The average village size was 112 households. In cases where a village exceeded the limit (200+ households), a hamlet within the village was selected. The range of village/hamlet sizes in the sample frame was: $75-125$ households in Riau/Jambi; 44-122 in Lampung; 83-144 in West Kalimantan; 67-89 in East Kalimantan; and 75106 in Central Sulawesi. 